\title{
2011s-48
}

\section{Alleviating Coordination Problems and Regulatory Constraints through Financial Risk Management}

Marcel Boyer, M. Martin Boyer, René Garcia

\begin{tabular}{c}
\hline Série Scientifique \\
Scientific Series
\end{tabular}

Montréal

Mai 2011

(C) 2011 Marcel Boyer, M. Martin Boyer, René Garcia. Tous droits réservés. All rights reserved. Reproduction partielle permise avec citation du document source, incluant la notice (C).

Short sections may be quoted without explicit permission, if full credit, including (C) notice, is given to the source.
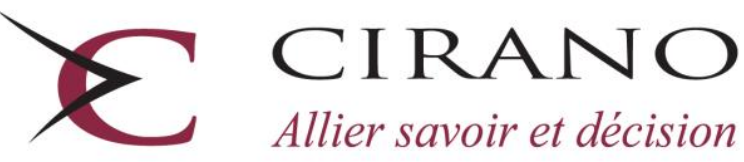

Allier savoir et décision

Centre interuniversitaire de recherche en analyse des organisations 


\section{CIRANO}

Le CIRANO est un organisme sans but lucratif constitué en vertu de la Loi des compagnies du Québec. Le financement de son infrastructure et de ses activités de recherche provient des cotisations de ses organisations-membres, d'une subvention d'infrastructure du Ministère du Développement économique et régional et de la Recherche, de même que des subventions et mandats obtenus par ses équipes de recherche.

CIRANO is a private non-profit organization incorporated under the Québec Companies Act. Its infrastructure and research activities are funded through fees paid by member organizations, an infrastructure grant from the Ministère du Développement économique et régional et de la Recherche, and grants and research mandates obtained by its research teams.

\section{Les partenaires du CIRANO}

\section{Partenaire majeur}

Ministère du Développement économique,

de l'Innovation et de 1'Exportation

\section{Partenaires corporatifs}

Autorité des marchés financiers

Banque de développement du Canada

Banque du Canada

Banque Laurentienne du Canada

Banque Nationale du Canada

Banque Royale du Canada

Banque Scotia

Bell Canada

BMO Groupe financier

Caisse de dépôt et placement du Québec

\section{CSST}

Fédération des caisses Desjardins du Québec

Financière Sun Life, Québec

Gaz Métro

Hydro-Québec

Industrie Canada

Investissements PSP

Ministère des Finances du Québec

Power Corporation du Canada

Rio Tinto Alcan

State Street Global Advisors

Transat A.T.

Ville de Montréal

\section{Partenaires universitaires}

École Polytechnique de Montréal

HEC Montréal

McGill University

Université Concordia

Université de Montréal

Université de Sherbrooke

Université du Québec

Université du Québec à Montréal

Université Laval

Le CIRANO collabore avec de nombreux centres et chaires de recherche universitaires dont on peut consulter la liste sur son site web.

Les cahiers de la série scientifique (CS) visent à rendre accessibles des résultats de recherche effectuée au CIRANO afin de susciter échanges et commentaires. Ces cahiers sont écrits dans le style des publications scientifiques. Les idées et les opinions émises sont sous l'unique responsabilité des auteurs et ne représentent pas nécessairement les positions du CIRANO ou de ses partenaires.

This paper presents research carried out at CIRANO and aims at encouraging discussion and comment. The observations and viewpoints expressed are the sole responsibility of the authors. They do not necessarily represent positions of CIRANO or its partners. 


\title{
Alleviating Coordination Problems and Regulatory Constraints through Financial Risk Management
}

\author{
Marcel Boyer ${ }^{\dagger}$, M. Martin Boyer ${ }^{*}$, René Garcia ${ }^{\S}$
}

\begin{abstract}
Résumé / Abstract
Nous caractérisons une entreprise comme un ensemble d'activités et de projets avec leurs flux financiers par état et période. Nous proposons une caractérisation de l'entreprise où les variations dans le prix de marché du risque induisent des ajustements dans la combinaison optimale d'activités ou de projets. Les modifications du portefeuille de projets génèrent des coûts de coordination. Nous proposons un nouveau rôle pour la gestion financière des risques en proposant que l'utilisation de titres financiers puisse réduire les coûts de coordination. Ce nouveau rôle de la gestion financière des risques est vérifié empiriquement, une fois pris en compte les facteurs explicatifs traditionnels de la gestion financière des risques.
\end{abstract}

Mots clés : Gestion des risques, valeur d'entreprise, problèmes de coordination, hedging, valeur à risque.

We characterize a firm as a nexus of activities and projects with their associated cash flow distributions across states of the world and time periods. We propose a characterization of the firm where variations in the market price of risk induce adjustments in the valuemaximizing combination of projects. Changing the portfolio of projects generates coordination costs. We propose a new role for financial risk management based on the idea that the use of financial derivatives may reduce coordination costs. We find empirical support for this new rationale for the use of financial derivatives, after controlling for the traditional variables explaining the need for financial risk management.

Keywords: Risk Management, firm value, coordination problems, hedging, value at risk.

Codes JEL : G32, D2, L2

\footnotetext{
* We thank Jean Tirole, Thomas Mariotti, Michel Poitevin, Richard Phillips, Gordon Sick, Sanjay Srivastava and Simon Van Norden for helpful comments on earlier versions of this paper, as well as seminar participants at Collège de France, Georgia State University, University of Toulouse, University Nova de Lisboa, European University of St. Petersburg, New Economic School in Moscow, University of Alberta, the European Group on Risk and Insurance Economics, Société canadienne de science économique, World Risk and Insurance Economics Congress, Northern Finance Association, Financial Management Association, and Risk Theory Society. We also thank SSHRC, FQRSC, CIRANO, Bell Canada, Hydro-Québec, the Bank of Canada, and MITACS for financial support. None of these individuals and organizations can be held liable in any way for the content of this article as we remain solely responsible for its whole content and all its shortcomings.

${ }^{\dagger}$ Bell Canada Professor Emeritus of Industrial Economics, Université de Montréal, and Fellow of CIRANO and CIREQ (marcel.boyer@ cirano.qc.ca).

^ CEFA Professor of Finance and Insurance, HEC Montréal, Université de Montréal, and Fellow of CIRANO (martin.boyer@hec.ca).

${ }^{\S}$ Professor of Finance, Edhec Business School, and Fellow of CIRANO and CIREQ (rene.garcia@edhec.edu).
} 


\section{Introduction}

The most recent theories for explaining the corporate use of financial derivatives are decades old. The convexity of the tax schedule was introduced by Main (1983), the reduction of bankruptcy and financial distress costs was mentioned in Booth et al (1984), the assessment of managerial quality was first proposed by DeMarzo and Duffie (1995) and Breeden and Vishwanathan (1996), managerial risk aversion dates at least to Stulz (1984), and, finally, capital expenditure and investment planning was presented in Mayers and Smith (1987). ${ }^{1}$ Since then no new theory, that has survived empirical testing, has been developed to explain the need for financial risk management.

In this paper we propose a characterization of the firm where variations in the market price of risk induce adjustments in the value-maximizing combination of projects undertaken by the firm. However, changing the portfolio of projects is costly since it means that the firm's specialists (plant or division managers for instance as in Hart and Moore, 2005) must agree and coordinate their efforts to alter the mix. We argue that financial derivative instruments can help lower coordination costs between the firm's specialists. The new viewpoint we develop is that financial risk management can alleviate coordination problems in complex modern firms.

We derive the prediction that the use of financial instruments will be more pronounced when the transformation possibility frontier (between the riskiness and expected value of project cash flows) is such that a small movement in the market price of risk will lead to important adjustments in the firm's portfolio of projects, a concept that we call reactivity. To test our model, we collected information for 269 large U.S. firms for the years 1993 to 2004. We first show that there is a strong relationship at the industry level between the level of reactivity and the use of financial derivative instruments. We then show using firm level data that reactivity has a significant positive impact on the number of risks that a firm manages using financial derivatives, even after controlling for other variables traditionally expected to have a significant impact on the use of financial derivative instruments. Our results are indeed consistent with Stulz (1996) stating "Perhaps more puzzling, however, is that many companies appear to be using [financial] risk management to pursue goals other than variance reduction" and Guay and Kothari (2003) suggesting that firms may be "using derivatives for purposes other than those predicted by traditional risk-management theory."

\footnotetext{
${ }^{1}$ Stulz (2004) provides a systematic review of the various theoretical justifications for risk management within a firm (see also Smithson and Simkins, 2005). For the convexity of the tax schedule, see also Smith and Stulz (1985), Graham and Smith (1999), Graham and Rogers (2002) and Graham (2003), as well as MacKay and Moeller (2003) and Adam, Dasgupta and Titman (2008) for the case of general cost convexity. For the lower expected cost of bankruptcy or financial distress, see also Smith and Stulz (1985), Block and Gallagher (1986), Mayers and Smith (1990), Nance et al. (1993), Geczy et al. (1997), and Bodnar et al. (1998). For managerial risk aversion, see also Smith and Stulz (1985) and Tufano (1996). For improving the investment decisions and for better planning of a firm's capital needs, Bessembinder (1991), Lessard (1991), Doherty and Smith (1993), Froot et al. (1993), and Holmström and Tirole (2000).
} 
We consider the firm as a nexus of projects and activities that give rise to a distribution function of cash flows across states of nature and time. In the spirit of a mean-variance world used in basic portfolio management theory, we derive an efficient frontier representing the firm's set of feasible projects and activities in a space with the expected value and riskiness of cash flows as coordinates. In this context, we adopt the view that production and operations managers aim mainly at raising the expected value of cash flows whereas real risk managers have as a main objective to reduce the riskiness of cash flows, thereby impacting the selection of projects and activities that give rise to the distribution of cash flows. This simplified structure captures, albeit in a much stylized way, characteristics of complex modern corporations: the distribution, communication and processing of information as in Bolton and Dewatripont (1984), the pervasive presence of specialists as in Hart and Moore (2005), the limited control of business units managers as in Dessein et al. (2005), and the decentralized functional authority framework as in Roberts $(2004)^{2}$

Given market conditions, all feasible combinations of projects and activities can be valued to identify the combination that maximizes firm value. As a result, firm value is determined by the portfolio of projects and activities and the market price of risk. As the market price of risk changes, a firm must adjust its portfolio of projects, thereby changing its aggregate distribution of cash flows, to achieve a new optimal position on its transformation possibility frontier. Depending on the shape of this frontier, the adjustments will be more or less pronounced. Movement towards the new optimal combination of projects may lead to disagreements between specialized functional managers or business units, given their respective specific objectives. We argue that such disagreements underwrite the use of financial instruments as a conflict resolution tool, thereby giving the financial risk manager a role as facilitator, if not coordinator, within the firm. Indeed, using financial instruments may provide important savings in view of the potentially high costs of aligning incentives among managers and business units or engaging in expensive reorganizations ${ }^{3}$. As usual, we find in our context that, in the absence of such coordination frictions, there is no role for financial risk management since investors could undo any financial transaction by a firm so that firm value is then independent of the financial risk management strategy (Titman 2002). ${ }^{4}$

\footnotetext{
${ }^{2}$ The trade-off between specialization benefits and coordination costs and the impact of such trade-off on organizational structure have been noted by many authors. See also Becker and Murphy (1993), Boyer and Robert (2006), Roberts (2004).

${ }^{3}$ Following discussions with senior corporate executives, we were comforted in the idea that coordination problems associated with major strategic activities, decisions and investments were tackled by high-level committees involving senior executives from different business units, firm-wide management functions and board representatives. A consensus must be reached before the reviewed investments, actions and changes in activities can be pursued and implemented (See Roberts 2004). Similar issues are also highlighted in The Renewed Finance Function - Extending Performance Management Beyond Finance, CFO Research Services, CFO Publishing Corporation, November 2007.

${ }^{4}$ Smith and Stulz (1985) and Jin and Jorion (2006) discuss a hedging irrelevance proposition similar to the leverage irrelevance theorem of Modigliani and Miller (1958): A firm cannot create value by hedging risks since investors bear the same cost of risk as the firm. This characteristic is present in our context as well.
} 
The transformation possibility frontier includes implicitly both technological and strategic characteristics of a firm. Our representation therefore captures the ability of a firm to change its risk characteristics through changes in its portfolio of projects. These changes may increase the value of the firm by decreasing its cash-flow beta (Stulz 2004) or by increasing it if doing so allows sufficiently higher expected cash flows. In the same spirit, we relate a firm's reactivity with respect to the market price of risk to its use of financial derivative products. Hence, in a world with no taxes, no bankruptcy or financial distress costs, and no agency conflicts between the different classes of stakeholders, there still exists a value-adding role for financial risk management as a relatively inexpensive tool to facilitate coordination and congruence of interests in the firm.

The simple theoretical and empirical findings we present support the idea that financial risk management alleviates coordination problems between different firm functions and divisions when changes in the firm's portfolio of projects become necessary. Our new rationale for corporate risk management theory, and the simple empirical test that we conduct, opens up a new area of research for further developing and testing the idea that the complexity of the modern firm may enhance the role of financial derivatives.

The remainder of the paper is organized as follows. We present the model of the efficient frontier and the value of a firm in Section 2. Section 3 discusses the reactivity of firms to changes in the market price of risk and captures the coordination problems that may emerge between risk managers and operations managers. It stresses the important role that financial risk management can play in alleviating these coordination problems. In Section 4, we conduct an empirical study to investigate the link between the use of financial instruments and the concavity of the transformation possibility frontier. Section 5 extends the basic risk model and discusses several issues from an industrial organization perspective. In addition, we illustrate how financial risk management can help in alleviating the impact on firm value of regulatory constraints such as VaR. We conclude in Section 6.

\section{The firm as a portfolio of projects}

\subsection{Preliminaries}

A firm is defined as a nexus of projects representing all real activities, such as those related to investment and production, and giving rise to a transformation possibility frontier for cash flows. This frontier is the envelope of all feasible vectors of cash flows over states of nature and time periods obtainable from all projects characterizing and identifying the firm as an economic entity. Hence, it accounts for all human, technological, contractual, legal and other constraints facing a firm. In the short term, a firm can modify its overall distribution of cash flows over states and time periods and switch from one distribution to another within its feasibility set by 
changing its portfolio of projects. In the long term, a firm can modify its feasibility frontier by changing constraints underlying the transformation possibility set, generally through technological and organizational innovations such as mergers, acquisitions and divestitures, or innovation and patent initiation.

If a firm can change its operations or increase its flexibility to significantly reduce its risk without changing expected cash flows, its market value will increase as the given expected cash flows will be discounted at a lower rate. Rather than characterizing a firm by its market beta, we see a firm as choosing, within its feasibility set, a portfolio of projects to obtain a distribution of cash flows that maximizes its value given the market price of risk. We therefore approach risk management from the general viewpoint of the economics of the firm rather than from the usual financial perspective, in the spirit of the early contributions of Fama and Miller (1972) and Cummins (1976).

To set ideas, we characterize in Figure 1 a firm by two blocks, real asset management and financial risk management. The first block is broken down into production and operations management (POM) on one hand, and real risk management (RRM) on the other. All activities within a firm, such as project selection, self-protection and self-insurance activities, can be described along these two dimensions. Financial risk management is purposely set apart and involves all transactions carried out through the purchase or sale of financial instruments.

\section{[Insert Figure 1]}

We first show how to construct the efficient frontier for a firm. This will involve the choice of a risk model to characterize the trade-offs between expected cash flows and risk. For simplicity, we start with a linear factor model, valid period by period, where all sources of risk are priced. We then establish how to calculate the value of a firm. It will involve deriving an optimal portfolio of projects given the market prices of risk factors.

\subsection{The possibility frontier and the market prices of risk factors}

A firm is a technology by which cash flows $c f_{s t}^{p}$ related to various projects $p \in\{1,2, \ldots, P\}$ defining a firm as an economic entity are distributed over or transformed between different states $s$ and periods $t$, with $s \in\{1,2, \ldots, S\}$ and $t \in\{1,2, \ldots, T\}$, under technological, legal, or contractual constraints. The transformation possibility frontier of firm $j$ (i.e., the envelope of all feasible cash-flow vectors) given its information set $\Omega_{0}$ at time $t=0$ can be represented as

$$
G_{j}\left(c f_{11}, \ldots, c f_{s t}, \ldots, c f_{S T} \mid \Omega_{0}\right)=0
$$


where $c f_{s t}$ is the aggregate cash flow over all projects $p$ in state $s$ and period $t$. The envelope of all feasible cash-flow vectors is assumed to be concave.

A firm modifies cash flows through changes in its portfolio of projects. Characteristics of the vector of aggregate cash flows lead to the firm's evaluation by financial markets. Given its technological possibilities represented by (1), a firm chooses the mix of POM and RRM activities to reach the vector of aggregate cash flows that maximizes its value. Hence, the frontier $G_{j}(\cdot)=0$ must be understood as the frontier that emerges from the POM and RRM activities. We later discuss the representation of financial risk management activities in this framework.

For presentation clarity, we now describe a multifactor model with $N$ orthogonal risk factors so that their mutual covariances are zero. We also assume, for simplicity, constant expected cash flows per period, $E_{s}\left(c f_{s t}\right)=E_{j}, \forall t$, and an infinite number of periods. The rate at which these constant expected cash flows should be discounted is given by:

$$
E R_{j}=R_{F}+\sum_{i=1}^{N} \beta_{j i}\left(E R_{i}-R_{F}\right)
$$

where $E R_{i}$ is the expected return on risk factor $i, R_{F}$ is the risk free rate, and $\beta_{j i}$ is the measure of risk with respect to the $i$-th factor. In such a setting, firm value is simply:

$$
V_{j}=\frac{E_{j}}{E R_{j}}
$$

Expressed in terms of cash flows, the security market hyperplane (2) takes the form:

$$
E_{j}=V_{j} E R_{j}=V_{j} R_{F}+\sum_{i=1}^{N} V_{j} \beta_{j i}\left(E R_{i}-R_{F}\right)
$$

where $V_{j} \beta_{j i}$ measures the risk of the firm's cash flows with respect to the $i$-th factor:

$$
V_{j} \beta_{j i}=V_{j} \frac{\operatorname{COV}\left(R_{j}, R_{i}\right)}{\operatorname{Var}\left(R_{i}\right)}=\frac{\operatorname{COV}\left(V_{j} R_{j}, R_{i}\right)}{\operatorname{Var}\left(R_{i}\right)}=\frac{\operatorname{COV}\left(c f_{j}, R_{i}\right)}{\operatorname{Var}\left(R_{i}\right)}=\frac{\operatorname{COV}\left(c f_{j}, R_{i}\right)}{\sigma_{i}^{2}}=\rho_{j i} \frac{\sigma_{c f_{j}}}{\sigma_{i}},
$$

where $\rho_{j i}$ is the correlation between the firm $j$ cash flows and the returns on the $i_{t h}$ risk factor, $\sigma_{c f_{j}}$ measures the volatility of the firm's cash flows and $\sigma_{i}$ measures the volatility of the return on the $i$-th risk factor. We can rewrite (4) as

$$
E_{j}=V_{j} R_{F}+\sum_{i=1}^{N} \rho_{j i} \sigma_{c f_{j}}\left(\frac{E R_{i}-R_{F}}{\sigma_{i}}\right)
$$


or

$$
V_{j}=\frac{1}{R_{F}}\left[E_{j}-\sum_{i=1}^{N} \rho_{j i} \sigma_{c f_{j}}\left(\frac{E R_{i}-R_{F}}{\sigma_{i}}\right)\right] .
$$

Given market values of $R_{F}, E R_{i}$ and $\sigma_{i}$, the value of a firm depends, in this context, only on $E_{j}$ and the $N$ scaled correlations $S C O R_{j i}=\rho_{j i} \sigma_{c f_{j}}$ between a firm's cash flows and market returns on the different risk factors.

Relative to valuing a firm, the variables $E_{j}$ and $S C O R_{j i} \equiv \rho_{j i} \sigma_{c f_{j}}, i \in\{1,2, \ldots, N\}$ are $N+1$ sufficient statistics of all projects within a firm. The transformation possibility frontier (1) can therefore be rewritten in terms of $E_{j}$ and $S C O R_{j i}$ as the envelope of all feasible points:

$$
H_{j}\left(E_{j}, S C O R_{j 1}, \ldots, S C O R_{j N}\right)=0
$$

We will work with this representation of a firm's technology. ${ }^{5}$

Defining a firm's feasibility set in terms of expected cash flows $E_{j}$ and the $N$ scaled correlation values $S C O R_{j i}$ has several advantages. First, it allows the value of RRM and POM activities to be measured by their capacity to move a firm toward or along the frontier $H_{j}(\cdot)=0$ in the $\left(E_{j}, S C O R_{j 1}, \ldots, S C O R_{j N}\right)$-space. A change in the mix of POM and RRM activities will usually generate a change of value. Second, it allows proper aggregation of risks at the firm level by establishing a functional relationship between risk factors and cash flows for the many projects or business units. Identifying risk factors that are common to the various projects and accounting for the dependencies between them is an important function, which can fall under the responsibility of a central unit or delegated to various units. The identification and measurement tasks are important functions of the chief operating officer, the chief risk officer and the chief executive officer.

\subsection{The value of the firm}

The value of a firm is generated by a mix of POM and RRM activities. For simplicity, one may represent POM (resp. RRM) as being intent on maximizing expected cash flows (resp. minimizing scaled correlations) for given scaled correlations of a firm's cash flows (resp. expected cash flows) with the $N$ different risk factor returns. Both activities thus contribute to the overall objective of maximizing value. In reality, these functions are often diffuse in an organization and sometimes shared by the same division. In this context, the primary responsibility of higher level executives is to ensure that a firm's decision making process brings it on its frontier.

\footnotetext{
${ }^{5}$ To draw the efficient frontier for a given firm, one needs the set of cash flows associated with the numerous projects defining the firm as a business entity along with the scaled correlations between the firm's cash flows and the returns on risk factors. Although the collection of such data is no small task, firms do undertake it, at least at some level of aggregation.
} 
For further simplicity, let us assume that there is a single risk factor, namely the market portfolio risk. This will allow us to develop the main ideas in a simple graphical fashion. With $S C O R_{j M}=\rho_{j M} \sigma_{c f_{j}}$, we can write (6) and (7) as: ${ }^{6}$

$$
\begin{gathered}
E=V R_{F}+V \beta\left(E R_{M}-R_{F}\right)=V R_{F}+S C O R_{M}\left(\frac{E R_{M}-R_{F}}{\sigma_{M}}\right), \\
V=\frac{1}{R_{F}}\left[E-\operatorname{SCOR}_{M}\left(\frac{E R_{M}-R_{F}}{\sigma_{M}}\right)\right] .
\end{gathered}
$$

From (9), we observe that $\beta \leq[\geq] 1$ as $S C O R_{M} \leq[\geq] V \sigma_{M}$. We can illustrate the problem of a firm in the $\left(E, S C O R_{M}\right)$-space as in Figure 2, where each dot represents a potential project or portfolio of projects with a $\left(E, S C O R_{M}\right)$ pair of coordinates. All projects a firm can undertake are represented in that space where the frontier is constructed as the minimum level of risk obtainable for a given level of expected cash flows (see Merton, 1972).

\section{[Insert Figure 2]}

We can represent iso-value lines as in Figure 3. By definition, an iso-value line represents combinations of $E$ and $S C O R_{M}$ giving the same market value. From (10), iso-value lines are linear and parallel, with slope equal to the market price of risk

$$
\theta_{M}=\frac{E\left(R_{M}\right)-R_{F}}{\sigma_{M}}
$$

\section{[Insert Figure 3]}

The value $V$ attached to a given iso-value line can be obtained by discounting the zero-SCOR expected cash-flow level $\left(C_{1}\right.$ and $C_{2}$ in Figure 3$)$ at the risk-free rate $R_{F}: V_{1}=C_{1} / R_{F}, V_{2}=$ $C_{2} / R_{F}$. Firm value increases in the North-West direction.

The combination of expected cash flows $(E)$ and scaled correlation between cash flows and market returns $\left(S C O R_{M}\right)$ that maximizes firm value is the combination at which the efficient frontier reaches the highest iso-value line. For that combination (point $A_{2}$ on Figure 3), the usual tangency condition holds:

Proposition To maximize its value, a firm must equate its marginal rate of substitution, the rate at which it can substitute POM and RRM activities while remaining on its efficient frontier, to the market price of risk:

$$
-\frac{\partial(O M)}{\partial(R M)}=-\left.\frac{\partial E}{\partial S C O R_{M}\left(c f_{j}, R_{M}\right)}\right|_{H\left(E, S C O R_{M}\right)=0}=\frac{E\left(R_{M}\right)-R_{F}}{\sigma_{M}} .
$$

\footnotetext{
${ }^{6}$ We will drop the index of firm $j$ when the context is clear and no confusion is possible.
} 
At $A_{2}$ on Figure 3, a firm cannot reduce its scaled correlation without reducing expected cash flows. At point $A_{1}$, however, the scaled correlation can be reduced without affecting expected cash flows because point $A_{1}$ is not located on the efficient frontier. A firm's POM and RRM strategies and policies are not efficient if they bring it to a situation such as point $A_{1}$. By better managing its real risk to reduce the scaled correlation of its cash flows, or by better managing operations to increase expected cash flows, a firm is able to increase its value. In this framework, the firm is assumed to maximize its value. Given that financial markets care about expected returns and risk, so does the firm. In so doing, the firm is not risk averse but rather sensitive to the way markets evaluate cash-flow distribution over states of nature and periods.

It is obvious that a $\mathrm{N}$-factor linear model will be an immediate extension to the single risk factor model we just described. A firm will maximize its value at the point of tangency between an efficient hyper-frontier and the highest reachable iso-value hyperplane. In Section 5, we also discuss how to account for unpriced risk factors and sketch a general intertemporal risk model. For the purpose of illustrating the role of financial risk management and motivating our empirical application relating the efficient frontier to hedging activities, we will maintain a simple one-factor risk model.

\section{$3 \quad$ Firm Value and Financial Instruments}

Developments in the previous sections dealt mainly with real asset management. This section covers the role of financial risk management. Our main argument will be that financial risk management is a relatively inexpensive way to facilitate coordination in responding to changes in market conditions. Changes in the price of risk alter the portfolio of projects and activities that maximizes firm value; this creates coordination problems that the financial risk manager can alleviate. Although the necessary changes in the portfolio of projects are the same with or without the presence of a financial risk manager, his presence allows the firm to achieve these changes at a lower coordination cost. When the market price of risk changes, the extent by which a firm's portfolio of projects must change depends on the distance between the old and the new portfolio of projects. If the efficient frontier is relatively flat, the change in the optimal portfolio involves a rather important reshuffling of projects. On the opposite, a less important change is needed if the frontier is more concave. The precise measure of the reactivity of the firm to changes in the market price of risk will be discussed in the next section.

Whereas the transaction costs associated with financial instruments are low, coordinating changes in real operations through the implementation of new projects or the abandonment of

existing ones typically entails substantial coordination costs. Moving from one optimal portfolio of projects to another involves a complex set of trade-offs in terms of increasing or reducing cash 
flows and increasing or reducing risk among the many organizational units of a firm, each mixing production and operations management activities and real risk management activities. Several cash flows-at-risk or value-at-risk constraints may also be imposed at various levels in an organization. We argue through a simple graphical illustration that financial risk management reduces the coordination cost of implementing the desired changes in real operations. As a result, firms that are more reactive to changes in the price of risk are more likely to use financial derivatives to make real adjustments less costly.

To understand and model these complex interrelationships, one needs to rely on the general theory of decentralization in hierarchies and on the theory of incentives under incomplete information. As evident in Mookherjee (2006), the theory of incentives has ignored so far the decentralization of risk management objectives. Moreover, aggregation of VaR targets in the risk management literature raises difficulties even abstracting from incentive issues.

To develop our argument while avoiding an unnecessarily complex modeling of the structural interactions in organizations, we assume a separation of objectives between real risk management, intent on reducing the $S C O R$ value (that is, favoring projects that contribute to that goal), and production and operations management, intent on increasing the $E$ value. Conflicts may therefore appear: the real risk manager will tend to oppose changes that increase the riskiness of cash flows $(S C O R)$ whereas the production and operations manager will tend to oppose changes that reduce expected cash flows $(E) .{ }^{7}$ Such a representation of the conflict between RRM and POM functions is admittedly extreme. It nevertheless characterizes in a simplified way the difficulties encountered when various managers need to coordinate their choices to maximize value. As mentioned above, major investments and policy or strategy decisions must typically gather a relatively large consensus among managers, executives and board members before being undertaken. ${ }^{8}$ We sketch below the coordination problems between RRM and POM in this simplified setting.

\subsection{Value creating coordination}

Suppose, for some reason, that a firm finds itself at a point on its efficiency frontier to the left of the optimal mix of POM and RRM activities as represented by point $A_{1}$ in Figure 4.

\section{[Insert Figure 4]}

\footnotetext{
${ }^{7}$ In large corporations bonuses are usually linked to cash-flow performance targets and less so to risk measures. Even option-based compensation rewards managers for cash-flow performance to the possible detriment of real risk management activities. With respect to the compensation of real risk managers, Gable and Sinclair-Desgagné (1997) and Sinclair-Desgagné (1999) offer an audit-like procedure to assess managerial performance in the context of environmental (real) risk management and control. An excellent cash-flow performance of a manager may be penalized if the audit procedure reveals that it has been achieved to the detriment of proper risk management.

${ }^{8}$ One can also think of coordination problems as being driven by organizational inertia, which emerges as different groups (or management functions) acquire quasi-veto rights on some changes in the activities of a firm. See Hannan and Freeman (1984) and Boyer and Robert (2006).
} 
If the POM manager continues trying to increase $E$ for a given $S C O R$, while the RRM manager keeps working to reduce $S C O R$ for a given $E$, the firm as a whole finds itself trying to move in an infeasible North-West direction. The way out of this efficient but not value maximizing combination of POM and RRM activities is for the RRM manager to let the SCOR increase above its current level, providing the POM manager with some leeway to increase $E$. In so doing, the RRM manager must momentarily destroy value, by letting SCOR increase given $E$, giving the POM manager the flexibility to ultimately increase firm value. The same argument can be developed for point $A_{2}$. In this case the POM manager must let $E$ decrease below its current level. In so doing, the POM manager must momentarily destroy value to give the RRM manager the possibility to reduce $S C O R$, thereby create value. In both instances, it is necessary for one manager to destroy firm value initially to allow the other manager enough room to eventually create more value. This level of coordination is clearly difficult as the former manager must assume some career risk.

\subsection{Firm reactivity and value creation through financial risk management}

We have thus far posited that in our framework with no taxes, no financial distress costs, no transaction costs of bankruptcy, and no agency problems, value is created within a firm only through its choice of real projects and activities. ${ }^{9}$ This means that maximal value is created only through an optimal mix of real activities, blending both POM and RRM ones. As the market price of risk changes, the optimal $E-S C O R$ combination of cash flows also changes, thus generating significant coordination problems. We will now show that financial risk management creates value by alleviating these coordination problems.

Consider Figure 5. Suppose a firm's optimal mix is initially at $A_{2}$ but because of a change in the market price of risk, the new optimal mix is at $A_{0}$. Suppose, moreover, that the POM manager is unwilling or unable to destroy positive net present value projects (moving down) to provide the RRM manager with enough flexibility to reach point $A_{0} \cdot{ }^{10}$ How can financial risk management help in this process?

\section{[Insert Figure 5]}

Consider the iso-value line that goes through point $A_{2}$. This line is, by definition, lower than the iso-value line tangent to the possibility frontier at point $A_{0}$. The slope of iso-value lines is the price of risk, that is, the price at which one can exchange risk, $S C O R$, for expected cash flows $E$

\footnotetext{
${ }^{9}$ This statement is clearly reminiscent of Proposition III in Modigliani and Miller (1958, page 288): “... the cut-off point for investment in the firm ... will be completely unaffected by the type of security used to finance the investment."

${ }^{10}$ Similarly, if we start at point $A_{1}$, the RRM manager is unwilling to create risk and destroy value to give the POM manager enough flexibility to reach point $A_{0}$.
} 
on financial markets. Therefore, under conditions of perfect financial markets and in a manner similar to an individual's portfolio choice under the two-fund separation approach, a firm can enter into financial transactions to move from $A_{2}$ to any point on the same iso-value line. These movements, for example to point $B$, are done at no cost, by assumption, but do not affect firm value since financial transactions are not creating value per se.

The advantage of moving a firm's $(E, S C O R)$ combination to point $B$ is that the RRM and POM managers are then given the mandate to move the firm from $B$ to $A_{0}$. What then is the value of financial risk management? In and of itself, the value is zero. Its value comes from the fact that it reduces the coordination costs to attain a new mix of risk and expected cash flows. Moving from $A_{2}$ to $A_{0}$ requires abandoning [accepting] some projects with positive [negative] net present value given the $S C O R$-coordinate at $A_{2}$, hence the normal opposition of the POM manager to those changes. Similarly, moving from $A_{1}$ to $A_{0}$ requires abandoning [accepting] some projects that are risk reducing [increasing] given the $E$-coordinate at $A_{1}$, hence the natural opposition of the RRM manager to those changes. But given the new $E$ and $S C O R$ coordinates at $B$, the real changes in the project mix to move the firm from $B$ to $A_{0}$ can now be agreed upon by both managers: the real changes are the same but they can be achieved at lower coordination costs.

\section{Empirical evidence on the link between firm reactivity and hedging}

Assuming that a firm can gather all the necessary information about future cash flows associated with its numerous projects, current and future, and given a risk model, it can construct at any time the type of efficiency frontier we have described in the previous sections. Obviously, this is not an easy and straightforward task. We analyze some of the difficulties in section 5.2 below. It is much harder to gather a panel of such data sets for several firms. Therefore, to test some implications of our characterization of the firm, we will adopt an indirect approach.

The important empirical implication of our firm characterization is that more reactive firms, having less concave possibility frontiers, will want to adjust their $(S C O R, E)$ position by larger margins when the market price of risk changes. Figure 7 illustrates our point.

\section{[Insert Figure 7]}

A firm whose possibility frontier is more concave will react less to changes in the market price of risk (moving typically from point $A$ to point $B_{\text {low }}$ in Figure 7 ) and therefore will need little change in its portfolio of projects and activities. On the other hand, a firm whose possibility frontier is less concave will see its optimal project mix change more (typically from point $A$ to point $B_{h i g h}$ ).

Our empirical analysis will proceed in two steps. First, we propose a measure of firm reactivity to risk price changes. Then, we want to link this reactivity to the use of financial derivatives since 
more reactive firms should be heavier users of financial risk management products to alleviate coordination costs associated with large changes in their portfolio of projects.

\subsection{Data Set Construction}

We build our data set starting from the 500 firms making up the Standard and Poor's 500 index. For all firms present in the index over the period 1993-2004, we gather annual accounting information and stock market information from annual Reports, Compustat, Bloomberg and CRSP, as well as derivative usage and managerial shareholding and option ownership from the EDGAR US Database. We provide in an appendix a list of all data items required for our empirical analysis with their source ${ }^{11}$. Not all data items were available for all firms over the sample period. In the end, we were left with 269 companies.

The distribution of firms across industries is given in Table 1. The manufacturing sector represents a large proportion of the total but this will not bear a significant weight on the results of our main analysis based on individual firms as long as there is enough cross-sectional variation in the reactivity of manufacturing firms. We will see that it is indeed the case.

\subsection{Measuring Reactivity and the Use of Financial Derivatives}

To compute the reactivity factor, we first measure the annual change $\Delta P_{j}$ in a firm $j$ position in the $(S C O R, E)$-space by the Euclidian distance between the firm positions in two adjacent years, scaled by the firm market value $V_{j}$ to control for size, that is:

$$
\Delta P_{j t} \equiv \sqrt{\left(S C O R_{j t}-S C O R_{j, t-1}\right)^{2}+\left(C F_{j t}-C F_{j, t-1}\right)^{2}} / V_{j t}
$$

where $S C O R_{j t}=V_{j t} * \sigma_{M t} * \beta_{j t}$, with $\sigma_{M t}$ being the volatility of market returns at time t, computed historically over the last two hundred trading days, and $\beta_{j t}$ being firm $j$ 's market beta in period $t$.

We then run a linear regression of the change in a firm's position $\left(\Delta P_{j t}\right)$ on the annual change in the market price of risk $\left(\Delta \theta_{t}\right)$ over the period 1993-2004, that is:

$$
\Delta P_{j t}=\alpha_{j}+\gamma_{j} \Delta \theta_{t}+\varepsilon_{j t}
$$

where $\Delta \theta_{t}=\theta_{t}-\theta_{t-1}$, with $\theta_{t}$ given by (11). The regression coefficient $\gamma_{j}$ is our measure of reactivity for firm $j$. Notice that it is an average measure over the sampling period that defines the structural characteristic of a firm.

\footnotetext{
${ }^{11} \mathrm{~A}$ longer appendix providing more details is available from the authors upon request.
} 
For the use of financial derivatives, researchers have most often used a dichotomous variable that takes the value 1 when the firm uses derivatives and 0 when it does not. This variable would leave us with two little cross-sectional variation between firms to identify the link between reactivity and use of derivatives. In our data set, we managed to collect use of derivatives for four types of risks for each firm. In the EDGAR database, as defined by US regulation, firms report hedging for equity risk, commodity risk, exchange rate risk, and interest rate risk. The first three are considered operational and the last one financial. Attributing a $(0,1)$ variable for each type of risk we can now count the number of risks a firm hedges. This is the variable we will use for our analysis.

To study the link between the reactivity measure we have constructed and this measure for the use of financial derivatives we will proceed first at an aggregate industry level. The idea will be to determine whether the more reactive industries hedge more risks. Then we will run a multivariate ordered probit with the number of risks as a dependent variable at the firm level to establish whether reactivity enters as a significant explanatory variable over and above the usual variables used to explain the hedging behavior of firms.

We will conduct our analysis for the cross-section of firms in 2004, the end-point of our sample. This will prevent to some extent endogeneity issues since the $\gamma_{i}$, the reactivity measures, are computed over a ten-year period (1993-2004) and all the other variables will take the value in the cross-section of 2004 .

\subsection{Estimation of the link between reactivity and hedging}

Before assessing the link between reactivity and the use of financial derivatives at the firm level we want to see if our hypothesis gets some empirical support at the industry level. To perform the analysis, we use the industry categories of Table 1 . The non-classified refers in fact to conglomerates, which are known to be heavy users of financial derivatives. We then add this reference category to see how it ranks in terms of reactivity.

\subsubsection{Industry level analysis}

We compute a given industry's reactivity by the $V_{i}$-weighted average of reactivity measures $\gamma_{j}$ (from regressions 13) of the firms in that industry. To compute the aggregate use of derivatives by an industry, we use four 0-1 variables indicating whether in 2004 a firm hedges or not a given risk, whose sum gives the number of risks hedged by a given firm. We then take the weighted average of those numbers, where the weights are the ratios of the market values of the firms over the total market value of the industry.

Table 2 presents the ranking of the twelve industries in terms of their estimated reactivity level $\gamma$, from the most reactive (Utilities) to the least reactive (Construction). The other columns of the 
table show the market-value weighted average number of operational risks (equity, commodity, and foreign exchange) that firms in that industry manage through the use of derivative contracts as well as the average number of total risks (operational plus interest rate) managed. The six most reactive industries (Utilities to Service) are those that are the top users of financial derivative contracts to manage operational risks. Although the ranking differs slightly when we add the use of interest risk derivatives, the same six most reactive industries remain the top six users of derivative contracts.

Figure 8 illustrates graphically the link between average industry reactivity and the average number of operational risks managed (a similar picture is obtained when the total number of risks is used). The linear relationship is of positive slope, which is significant at the five-percent level, and no industry appears in the second and fourth quadrants.

\section{[Insert Figure 8]}

\subsubsection{Firm level analysis}

We now examine the relationship between the estimated reactivity level $\gamma_{j}$ and the number of operational risks managed at the firm level in 2004. The number of firms in the sample is reduced to 238 as we dropped the 31 firms in the financial industry since some variables (quick ratio, foreign sales and reserves) are not computed in the same way as in other industries. Moreover, financial firms are both users and providers of financial derivatives. Of the firms in the sample, $29.8 \%$ use no derivative instrument to manage operational risk, $50 \%$ manage only one risk through derivatives, $18.5 \%$ two risks, and $1.7 \%$ manage all three risks.

We use a ranked probit approach. ${ }^{12}$ The dependent variable is the number of operational risks that a firm manages using derivatives. Therefore, this variable takes the value $0,1,2$ or 3 . We use the following explanatory variables. First and foremost we want to include the variables that previous studies have chosen to explain the use of financial derivatives by firms to hedge risk. These include the quick ratio (current assets minus inventories divided by current liabilities), the ratio of foreign sales to total sales, and the carry-forward of net operating losses over the total assets: the higher the first ratio is, the less need there is for a firm to hedge; a firm with significant foreign operations will be subject to currency risk and will therefore be more likely to use foreign exchange derivatives; finally, the last variable measures the tax benefit that can be obtained by carrying forward losses. These three variables are the traditional measures included in hedging studies for leverage, foreign exposure and convexity of the tax schedule. ${ }^{13}$ The fourth traditional

\footnotetext{
${ }^{12}$ De Angelis and Garcia (2008) show the advantage of such a ranked approach over a simple logit for the use of derivatives or a Heckman-type two-step approach.

${ }^{13}$ See Graham and Rogers (2002), Allayannis and Weston (2001), Allayannis and Ofek (2001), Graham and Smith (1999).
} 
variable related to the use of financial derivatives is the size of the firm ${ }^{14}$ and we measure it by the logarithm of the firm assets.

A potential problem with using S\&P500 firms is to overrepresent large firms in the sample. Since large firms tend to use more financial derivatives because of the large fixed cost of using derivatives, one may argue that we lack cross-sectional variation to support reactivity as a reason for hedging due to implicit coordination costs. To address this issue, we control for size in our ordered probit analysis.

Graham and Rogers (2002) argue against the net operating losses as a proxy for measuring the tax benefit and propose a refined measure using the Graham and Smith (1999) approach to explicitly measure tax function convexity. This technique quantifies the convexity-based benefits of hedging by determining the tax savings that result from reducing volatility. Another explanatory variable often used to explain the hedging decision is a ratio of long-term debt to the assets of a firm. ${ }^{15}$ However, it is usually the interest rate risk that is considered when accounting for the tax incentive to hedge by increasing debt capacity. ${ }^{16}$ We include this variable but considering that we do not include the use of interest rate derivatives we do not expect this variable to be significant.

Our purpose is to verify that our reactivity variable still plays a significant role after controlling for the tax benefit effect and that we find a significant effect for net operating losses as in the previous studies using this proxy. This is indeed the case.

We estimate the probit model by maximum likelihood. ${ }^{17}$ The results are reported in Table 3 , where a coefficient (together with a p-value) refers to the impact of that variable on the probability that the firm hedges a greater number of operational risks. All four traditional variables above come out with the expected sign and are significant at close to the $5 \%$ level, especially after controlling for the industry effect. Therefore, our analysis confirms the findings of previous studies. More importantly for the purpose of this paper, however, the results in Table 3 show quite clearly that reactivity has a statistically significant positive impact on the number of operational risks managed with financial derivatives. This result, together with the previous ranking of industry reactivity and use of derivatives, supports our hypothesis that a firm's sensitivity to the market price of risk is a strong determinant of the use of financial derivatives, in addition to the traditional reasons for hedging such as leverage, foreign exposure, convexity of the tax schedule, and size.

To capture the role of financial risk management in alleviating coordination problems we also introduce the number of business segments in a firm ${ }^{18}$. This is certainly an imperfect measure of coordination problems or costs but it indicates that the hierarchical structure is important over and above the mere size of the firm. Its clear significance reinforces the link between hedging and

\footnotetext{
${ }^{14}$ See among others Nance et al. (1993).

${ }^{15}$ See among others Graham and Rogers (2002).

${ }^{16}$ Graham and Rogers (2002) also find that hedging leads to greater debt capacity.

${ }^{17} \mathrm{~A}$ full description of the variables included in the probit is given in the appendix.

${ }^{18}$ See the appendix for a description of how this variable was constructed
} 
the complexity of the firm's activities. We present also results with a control for the industry to which a firm belongs. In this case we prefer not to include business segments. ${ }^{19}$ The results remain robust and are practically the same as without the control for industry.

We have also included in the probit model other variables that some previous studies have used to explain hedging such as dividend policy, the book-to-market ratio, and the security holdings of the managers in the firm to account for risk aversion in agency frameworks ${ }^{20}$. None of those is significant at reasonable levels of confidence.

For robustness purposes, we ran a series of other regressions that for space considerations we do not report. We started our investigation by running a simple logit, where we considered only the use or no-use of derivatives as the dependent variable. The usual hedging variables came out with the right sign and were significant except for the net operating losses, while the reactivity variable had the right sign but with a coefficient twice as small and a p-value of 0.35 . Obviously accounting for the number of risks adds useful information to the regression to identify the propensity of a firm to use derivatives with more or less intensity ${ }^{21}$.

We have also tried other measures of reactivity based on the curvature of the frontier instead of the distance between the expected cash flow - risk positions. The results were similar but less significant. Finally, we included the beta of the firms to control for the level of risk but it did not come out significant ${ }^{22}$.

\section{Discussion}

In this section we extend the analysis in different directions. We first discuss extensions of the basic risk model, then we point to the problems of acquiring the proper information to draw the efficient frontier, and finally we mention some implications of our analysis from an industrial organization perspective.

\footnotetext{
${ }^{19}$ The number of segments was collected in the annual reports of the firms. Given how Compustat classifies a company's industry it would be econometrically unsound to include both the number of business segments and industry control dummies in the same regression. For instance Compustat has one industry category called "non classified" that clearly includes the large conglomerates purely on the basis of the number of business segments. Also there are industries where the choice of business segments is more refined than in other industries and the number of business segments to report is determined by the firm (see Harris, 1998), which induces a systemic bias in the number of business segments across industries.

${ }^{20}$ For the determination of managerial shareholding and option ownership, we analyzed the portfolio of the top five executives of the firm as in Ofek and Yermack (2000).

${ }^{21}$ In a very thorough econometric analysis, DeAngelis and Garcia (2008) show the advantage of using a ranked probit instead of a simple logit with an indicator variable for the use of derivatives.

${ }^{22}$ The cross-sectional correlation between the $\gamma_{j}$ of the firms and the betas in 2004 was -0.25 . We computed this correlation with the betas for other years and always found a negative number of a similar magnitude. One can argue that there should be a negative relation between the beta of a firm and its reactivity factor. A firm that can change its activities easily after a variation in the price of market risk should be less risky.
} 


\subsection{Extensions of the basic risk model}

To show that the approach is not limited to the simple risk model analyzed above, we briefly discuss two important extensions. First, we account for the fact that not all risks are priced by the market. This will not prevent the firm from optimizing, as we will explain. Second, and more importantly, we set the trade-offs between expected cash flows and risk in a dynamic framework through a general stochastic discount factor. This formulation will be compatible with many risk model specifications and encompass the linear multifactor model specified in the previous section.

\subsubsection{The case of non-valued risks}

We have assumed until now that all the risk factors have a market price, so that firm value maximization is achieved at the optimal tangency point between the iso-value hyperplane and the possibility frontier. When the market does not value some risks that are nevertheless taken into consideration by a firm, the valuation problem is different.

We can illustrate this situation with two risk factors: the first is valued by the market and is represented by the market portfolio while the second is managed by the firm at some cost but is diversifiable for an outside investor so that its market value is zero. At what optimal level should a firm manage this non-valued risk? Each level of non-valued risk corresponds to a projected transformation possibility frontier in the space expected value - market-valued risk, namely $H\left(E, S C O R_{M} \mid S C O R_{N V}\right)=0$, where $S C O R_{N V}$ is the level of non-valued risk taken or assumed by a firm. Under some reasonable assumptions about the non-valued risk (including the existence of a unique global maximum), there is one best or maximal transformation possibility frontier in the space expected value - market-valued risk, namely $H\left(E, S C O R_{M} \mid S C O R_{N V}^{*}\right)=0$. The tangency point between the highest iso-value line and this maximal frontier gives the maximal market value of a firm. ${ }^{23}$

\subsubsection{An Intertemporal Framework}

In the simple risk model we specified earlier, we have sidestepped the problem of computing the present value of intertemporal cash flows by assuming a flat term structure and a constant risk measure over time. Therefore, the transformation possibility frontier did not change over time. In a more realistic setting where risk and return change over time, we need to compute at each point in time, say $t$, an efficient frontier $H_{t}\left(E_{t}, S C O R_{t}\right)=0$, where $E_{t}$ and $S C O R_{t}$ group all the conditional expected values and scaled correlations. The extension to an intertemporal framework

\footnotetext{
${ }^{23} \mathrm{~A}$ parallel can be drawn with the production function using a non-valued or zero-cost input, such as water or air. If production affects the quality of this input, there will be an optimal amount of activity, say in terms of quantity of pollutants rejected, that will be compatible with maximizing profit. Similarly, there will an optimal amount of non-valued risk that a firm should take or assume in order to maximize its market value in the (expected value, market-valued risk)-space. In so doing, a firm optimally manages this non-valued risk.
} 
can be set in an Arrow-Debreu type economy or in a world with a general stochastic discount factor. In such intertemporal extensions, the price of risk and the price of time will play a role in the marginal trade-offs the firm will engage in, both across states of nature and periods.

To be as general as possible, we need not specify a linear risk model. We can rely on the existence of a stochastic discount factor, say $m_{t, T}$, which gives the value in $t$ of a cash flow in $T$, in the absence of arbitrage opportunities. The value in $t$ of any project within a firm with associated cash flows $C_{t+1}, \cdots, C_{T}$ from $t+1$ to $T$ is then given by:

$$
P_{t}=E_{t}\left[m_{t, t+1} C_{t+1}+\ldots+m_{t, T} C_{T}\right]
$$

By the covariance formula, we can rewrite this expression as the sum of two distinct blocks, one for products of expectations, the other for covariances:

$$
P_{t}=E V_{t}+C O V_{t}
$$

with:

$$
\begin{aligned}
E V_{t} & =E_{t}\left[m_{t, t+1}\right] E_{t}\left[C_{t+1}\right]+\cdots+E_{t}\left[m_{t, T}\right] E_{t}\left[C_{T}\right] \\
C O V_{t} & =\operatorname{Cov}_{t}\left(m_{t, t+1} C_{t+1}\right)+\cdots+\operatorname{Cov}_{t}\left(m_{t, T} C_{T}\right)
\end{aligned}
$$

The expectation terms $E_{t}\left[m_{t, \tau}\right]_{\tau=t+1}^{T}$ provide the prices of zero-coupon bonds for corresponding horizons $\tau=t+1, \cdots, T$. An efficiency frontier can then be defined in terms of $\left(E_{t}, C O V_{t}\right)$ as before, but now the frontier will change at each period depending on the evolution of the term structure of interest rates and of the risk measures embedded in the stochastic discount factors. Since all quantities have been discounted at time $t$ accounting for both the values of time and risk in cash flows over time and states of nature the iso-value lines will have a slope of one. Of course the analysis of the trade-offs between expected cash flows and risk or between different risks becomes more involved but remains possible once a specific content is given to the stochastic discount factor through a model. ${ }^{24}$

\footnotetext{
${ }^{24}$ When the stochastic discount factor corresponds to the CAPM or the linear multifactor model described in section 2.2, the trade-offs can be expressed between expected cash flows and scaled correlations. To obtain a similar separation of parameters leading to the use of scaled correlations with the general specification in (14), more structure is needed in the stochastic discount factor. For example, one can extend the factor model described earlier to a dynamic factor model where the scaled correlations will change over time, assuming, for simplicity, that the term structure of interest rates is flat.
} 


\subsection{Caveats on information acquisition}

In deriving the transformation possibility frontier between the expected value of projects and their risk, we have assumed away technical or informational issues. Such issues could prevent a chief executive officer from implementing the necessary trade-offs. We will sketch below the main obstacles such as incomplete and asymmetric information, indivisibility and transaction costs.

A first obvious problem is the significant data collection implied by the dimension of the problem. Projects, active and inactive, are numerous in a firm and obtaining the corresponding cash flows over time is no small task. The information collected is also likely to lack precision. Therefore, the frontier may be derived under imprecise and potentially incomplete information, and uncertainty will prevail as to its exact position. This uncertainty will directly affect determination of the optimal mix of production and risk management activities.

A parallel with mean-variance optimization in asset allocation will help us gauge the extent of the problem. It is well known in this literature that small changes in the assumed distribution of asset returns often imply large changes in the optimized portfolio. Many portfolios may be statistically as efficient as the ones on the efficient frontier. Several statistical solutions have been proposed to account for the variability of the efficient frontier (see Michaud, 1998) and to increase the stability of the optimal portfolio (Jagannathan and Ma, 2003). Beyond these statistical solutions, one can mitigate the uncertainty associated with a detailed computation of intertemporal cash flows by aggregating projects among various organizational units. This will make the problem of gathering data generally easier given the accounting system already in place and facilitate the optimization process.

Asymmetric information could also prevent a firm from attaining the project mix that maximizes its value. Adverse selection and moral hazard problems can impede the process of gathering information at every level of a firm's hierarchy (see Williamson 1967). Managers may propose projects that have been selected on criteria other than maximizing firm value. The collection of projects from which the frontier is drawn may not, therefore, be the right one and the final mix of projects will be suboptimal. Solutions for these problems are the usual incentive schemes that will help elicit the right information.

Another important difficulty in drawing up a possibility frontier for a firm lies in the indivisibility of real assets. In portfolio theory with infinitely divisible financial assets, it is always possible to be arbitrarily close to the efficient point on the frontier. With real activities, some projects must be undertaken completely or not at all. A numerical search for the optimal mix of activities has to proceed differently, but it is still possible to arrive at a frontier. It will not have the smooth appearance that we drew in our graphs but it will keep its optimality property. Similarly, some constraints may be imposed on the minimal size of projects in deriving the optimal frontier. 
Transaction costs may explain why a firm does not want to continuously change the optimal mix of projects. For example, premature termination of a project may involve penalties in terms of labor compensation or legal fees. A change in the optimal mix may also be postponed because of fixed costs associated with the disposal of fixed assets. Incorporating these transaction costs in portfolio choice is an extremely difficult theoretical and computational issue. Only partial solutions with specific cost structures, often unrealistic, are available. Transaction costs associated with a change of policy are just one example of sunk or irreversible costs. When a project in under way, managers may induce some changes that will affect its future cash flows; this is another potentially important source of costs.

\subsection{An application to $V a R$ and $C a R$ constraints}

Another implication of our framework concerns regulatory or self-imposed cash flows-at-risk (CaR) or value-at-risk (VaR) constraints. We show in this section that a firm can, through appropriate financial risk management operations, meet these financial constraints without changing its value maximizing activities and therefore without any impact on its market value. This suggests that, because of the $\mathrm{VaR}$ and $\mathrm{CaR}$ constraints they face, firms in regulated industries such as financial services and public utilities will be heavier users of derivatives and other financial risk management instruments.

A cash flow-at-risk constraint imposes the requirement that the cash-flow shortfall $E(c f)-$ cf will surpass a desired level $(C a R)$ with a given probability $\alpha: \operatorname{Pr}[E(c f)-c f>C a R]=\alpha$. These constraints, when binding, are usually perceived as preventing the maximization of firm value. Every $(E, S C O R)$ combination can be associated with a $C a R$ value. Iso- $C a R$ curves, that is curves on which all points have the same $C a R$ value, can be drawn. On Figure 6, the $C a R$

value at point $A_{H}$ is the same as at point $D$. Let us identify this curve as $C a R_{H}$ and suppose that a firm is required to satisfy that $C a R_{H}$ level.

\section{[Insert Figure 6]}

A firm's value is not maximized at point $A_{H}$ since the iso-value line through $A_{H}$ lies below the isovalue line through $A_{L}$, the value maximizing point. The project mix in $A_{L}$ is certainly attainable given the possibility set of the firm, but $C a R_{L}$, the iso- $C a R$ curve through point $A_{L}$, does not satisfy the constraint. As a result, the difference in firm value between $C_{L} / R_{F}$ and $C_{H} / R_{F}$ represents the cost of the $C a R$ constraint.

With perfect capital markets, a firm is always able to trade zero-value financial contracts at no cost to move along the iso-value line whose slope is the market price of risk. Then, such a movement with financial instruments along the iso-value line going through $A_{L}$ can bring the firm to point $D$, which satisfies the $C a R$ requirement. At point $D$, firm value is equal to $C_{L} / R_{F}>$ 
$C_{H} / R_{F}$ since point $D$ lies on the same iso-value line as $A_{L}$. Again, value is not created by financial risk management per se. It simply makes a firm obey a $C a R$ constraint while keeping its optimal mix of real activities. This would have been infeasible without the use of financial instruments.

Therefore, $C a R$ constraints should have no impact on the market value of firms under perfect capital markets. Hence, a firm should instruct its real asset managers (POM and RRM) to maximize its value and then ask the financial risk manager to use financial transactions to satisfy the $C a R$ requirement. Consequently, financial risk managers in industries with binding $C a R$ regulation, such as the financial services industry, will use more zero net present value financial contracts that reduce a firm's risk and expected cash flows (typically from $A_{L}$ to $D$ in Figure 6) in order to attain the risk-return constraint set by the regulatory body, at no cost in terms of firm value.

\subsection{Implications for Industrial Organization Analysis}

Despite its arguably abstract nature, our financial and real risk management model leads to several empirical implications for industrial organization analysis. We discuss below some of our results in the context of this literature.

Our empirical analysis shows that firms whose cash flows are more reactive to changes in the market price of risk are more likely to use financial risk management instruments. An interpretation of this result is that the use of financial derivatives facilitates the resolution of coordination problems between line managers, a problem that is more likely to occur when changes in the project mix are important. Our argument thus suggests that multi-industrial and multinational firms, that have a more diverse project mix than single-industry single-country firms, as well as firms with significant growth options, will be heavier users of derivatives. ${ }^{25}$

Larger corporations are more likely faced with more challenging coordination problems simply because of their wider dispersion of real assets and extensive distribution of responsibilities. ${ }^{26}$ Indeed, Nance et al. (1997), Mian (1996) and Graham and Rogers (2002) have shown that financial risk management procedures and products, such as forwards, futures, swaps, and options, are more common in larger firms. ${ }^{27}$ These empirical regularities contradict theories in which the

\footnotetext{
${ }^{25}$ Indeed, Geczy et al. (1997) find that firms with extensive foreign exchange-rate exposure (like multinational firms) are more important users of derivatives; He and $\mathrm{Ng}$ (1998) maintain the same in the case of conglomerates; and Nance et al. (1993) find that firms with significant growth options use more derivatives.

${ }^{26}$ With respect to size, for instance, Bodnar et al. (1998), Nance et al. (1993) and Geczy et al. (1997) show that larger firms hedge more through the use of derivatives than smaller firms, even though their expected bankruptcy costs are relatively lower. Whereas Block and Gallagher (1986) and Booth et al. (1984) argue that larger firms engage in more financial risk management because of the large fixed costs involved to hedge financial risks, we argue instead that they do so because, relative to smaller firms, they experience more difficult coordination problems. Firms present in more business segments, such as multinational firms and conglomerates that have a more diverse project mix than single-industry single-country firms, will likely experience more important coordination problems, hence should be greater users of derivatives.

${ }^{27}$ See also the results from the Wharton-Chase survey (1995) and the Wharton-CIBC Wood Gundy survey (1996)
} 
value of financial risk management is based upon the reduction of the cost of financial distress. Stulz (1996) writes:

"The primary emphasis of the [corporate risk management] theory is on the role of derivatives in reducing the variability of corporate cash flows and, in so doing, reducing various costs associated with financial distress. The actual corporate use of derivatives, however, does not seem to correspond closely to the theory. For one thing, large companies make far greater use of derivatives than small firms, even though small firms have more volatile cashflows, more restricted access to capital, and thus presumably more reason to buy protection against financial trouble. Perhaps more puzzling, however, is that many companies appear to be using [financial] risk management to pursue goals other than variance reduction."

Guay and Kothari (2003) considered the magnitude of risk exposure hedged by financial derivatives in 234 large non-financial corporations using derivatives. Their results show that the amounts involved are relatively modest relative to firm size and operating and investment cash flows. The authors state that "Although our results suggest most firms hold derivatives positions that are small in magnitude relative to entity-level risks," their results are potentially consistent with, among other factors, "firms using derivatives for purposes other than those predicted by traditional risk-management theory." (p.426)

These empirical regularities are compatible with the predictions of our model. To justify the greater use of financial derivatives by large firms, previous studies have invoked the large costs of setting up a risk management function. Besides this cost argument, we propose that financial risk management alleviates reorganization and coordination costs, which is a different objective from a variance reduction one. Another test would be to compare corporations where the number of executives who have a say in project approval is large with corporations where that number is small. Because financial risk management is more valuable for corporations that have major coordination problems, our model predicts that firms with a larger number of executives involved in project selection will use more financial risk management techniques. We are not aware of any study on that topic.

Finally, our model leads to a renewed consideration of the use of financial hedging instruments by firms subject to regulated or self-imposed financial constraints, such as value-at-risk or cash flow-at-risk constraints. We showed (Figure 4) that financial risk management could, through the use of zero-value contracts, allow firms to meet those constraints without sacrificing firm value. Our model suggests therefore that, because they are typically subject to stringent financial

as mentioned in Stulz (1996, page 9): "Whereas $65 \%$ of companies with a market value greater than $\$ 250$ million reported using derivatives, only $13 \%$ of the firms with market values of $\$ 50$ million or less claimed to use them." See also Boyer and McCormack (2009) for more recent evidence in the manufacturing sector. 
constraints of the VaR and CaR types, firms in sectors such as financial services and utilities will be among the heavier users of derivatives and other financial risk management instruments. The reason we elicit here for this significant use of financial risk management procedures and products is clearly different from the standard argument, namely the reduction of financial distress cost.

\section{Conclusion}

The goal of this paper was to offer a new theory to explain the use of financial risk management tools such as derivatives in non-financial firms. Modern financial economic theories on the topic are decades old so that no new theory has been empirically validated since the mid eighties. The new theory we develop is based on the principle that coordination problems between different firm functions (real operations) are alleviated through financial operations. Empirically, our theory implies that the more reactive a firm is to changes in the market price of risk, the more prevalent will be the use of financial derivatives.

Using time series from 1993 to 2004, we measured this reactivity factor for 269 large U.S. firms. We then related reactivity to the use of financial derivative instruments. First, we found that there is a strong relationship at the industry level between the aggregate measure of reactivity and the use of derivatives. Second, we constructed a probability model at the firm level to explain the number of operational risks managed though financial derivatives. We found a strong and significant role for the reactivity factor in this relation, even after controlling for firm size, leverage, foreign exposure, and the convexity of the tax schedule. We then concluded that the reactivity factor, a measure of the concavity of the possibility frontier, is an important determinant of a firm's use of financial risk management instruments.

The framework we present shows that both real and financial risk management can add value to a firm. Contrary to the current academic view of financial risk management, which makes it a special purpose function of a corporation rather than an integral part of decision making, we proposed a characterization of firms as nexus of projects defined by their expected cash flows and risk, where both financial and real risk management activities appear alongside operations in maximizing firm value.

We were then able to define a transformation possibility set for a firm. In this context, the object of production and operations management is to raise expected cash flows while real risk management aims to lower risk. By choosing the projects to invest in, managers search for efficiency (i.e., attaining the frontier of possibilities) as well as for optimality (i.e., reaching the point on that frontier that maximizes firm value given the market prices of risk factors). Conflicts arise when managers, obeying or reacting to different incentive contracts or objectives, do not view the projects as having the same potential contribution to firm value. This is where financial 
risk management can help a firm in maximizing value.

The facilitating role of financial risk management is crucial whenever changes in the market price of risk induces important changes in the optimal set of projects and activities. Our empirical strategy rests precisely on identifying how much a firm reacts to changes in the market price of risk: a firm's reactivity depends on the relative concavity of its possibility frontier. Our interpretation of this relationship is that more reactive firms are likely to face important coordination problems in maximizing their value and that financial risk management facilitates coordination. It is through such facilitation that financial risk management indirectly contributes to firm value, especially in a context where real asset management activities are decentralized.

Access to micro data sets on firms could lead to the estimation of risk-reward frontiers, that is, frontiers expressed in terms of risk and expected cash flows. This could lead to a refined analysis of the links between characteristics of the efficient frontier, market parameters and organizational characteristics of the firm. This opens a fascinating new avenue to study the relationship between firm value and risk management. 


\section{Appendix - Data Set Description}

\subsection{Accounting and Market Data}

Accounting data included in the database have been extracted from Compustat. Information about betas, risk premium and risk free rate have been extracted from CRSP. Below we describe how each variable was computed from the original items available in Compustat. The numbers refer to the item number in Compustat. A full list of the available items in Compustat is contained in a more complete Appendix available upon request from the authors.

- MV Value: Firm's market value calculated as the number of shares out- standing times the stock price at fiscal year-end: Data25 × Data199.

- Book Value: Firm's book value calculated as total assets minus intangibles and total liabilities, (Data6 - Data33 - Data181).

- Div Yield: Dividend paid by share by the stock's price: Data26 / Data199.

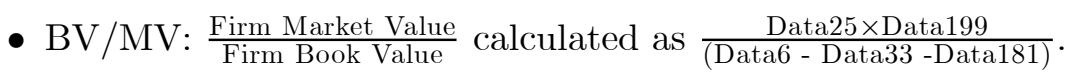

- LT Debt/MV: Firm's long term debt by its market value, $\frac{\text { Data9 }}{\text { Data25 - Data199 }}$

- R\&D Expenses: Data46

- Assets: Total assets, Data6

- Liabilities: Total liabilities, Data181

- R\&D/Assets: R\&D expenses by total assets, $\frac{\text { Data46 }}{\text { Data6 }}$

- Employees: Data29

- Foreign currency Adj: Foreign currency adjustment, Data150

- Cash: Cash and short-term investment, Data1

- Inventories: Data3

- Current Assets: Data4

- Current Liabilities: Data5

- Quick Ratio: $\frac{\text { Current Assets - Inventories }}{\text { Current Liabilities }}=\frac{\text { Data4 - Data3 }}{\text { Data5 }}$

- Deferred taxes: Data269+ Data270 + Data271 
- Investment tax credit: Data208

- NOL carryforward: Net Operating Losses Carryforward, Data52

- RP: Risk Premium variation calculated as $X_{t}-X_{t-1}$

- SCOR: Calculated as Firm Market Value $\times \beta \times \sigma_{m}$

- $\mathrm{E}(\mathrm{CF})$ : Firm Cash Flows or Operating earnings before depreciation, Data13

- Shares Outstanding: Number of common shares outstanding at fiscal year- end, Data25

- Stock Price: Price of the common stock at fiscal year-end, Data199

- Capital Ex.: Capital expenditures, Data145

\subsection{Hedges and Derivative Instruments}

Disclosures about hedges and derivatives instruments are included in Item 7a - Quantitative and Qualitative Disclosure about Market Risk and in different notes from Notes to consolidated Financial statements included in Item 8 Financial Statements and Supplementary Data from the annual report on Form 10-K.

Under Item 7a we found information related to the type of particular market risk and exposures faced by the firm. In addition, we may have found some information about instruments used for hedging. However, fair market value and notional amounts of contracts entered into are usually not disclosed in that section. Still we have looked to this section in order to have a general idea about the hedging policy of the company and the type of risk hedged. If no derivative instruments were contracted during the period covered by the study, it is in this section that we have collected the information.

The greatest part of the data on hedging was collected from the Notes to consolidated Financial statements. Firms reported their derivatives activities for hedging purposes on their annual report through a note on financial instruments or either on a separate note dedicate specifically to hedging instruments and policies. In this type of note on financial instruments we found a description of the type of instrument used and for what purpose (hedging or trading) it was entered into. Subsequently, firms report the carrying value, the fair value and sometimes the notional value of their instruments in accordance with the FASB's disclosure requirements.

We have looked at derivatives instruments used for four different types of risks:

- Foreign exposure

- Debt and interest rate related 
- Commodities

- Equity

We reported the management of such risk with derivatives by a binary variable ( 1 if the exposure is hedged with derivatives). We also report in the database the aggregate notional (when disclosed), the total fair value of derivatives and finally the fair value of instruments grouped by the type of risk hedged.

While regulation by the FASB about derivatives requires that companies disclosed the type of instruments they use and the fair value of those same instruments, it appears that companies report such use of derivatives in ways that are quite unequal and different. When we could not gather the data at the level of detail we required we did not include the firm in our sample. More details on the method of data collection can be found in examples in a supplementary appendix available upon request from the authors.

\subsection{Managerial Ownership}

For managerial ownership we collected both stock ownership and options ownership. In order to have information on a comparable basis between firms, we reported the ownership of the top five named executive officers of each firm. Data on beneficial ownership of managers were usually found in the Notice of Annual Meeting of Stockholders (the proxy statement) on form DEF 14A. In this proxy statement, under the section Executive Compensation, companies disclosed the value of unexercised (exercisable and unexercisable) options at fiscal year-end for the CEO and for their five most compensated executive officers. We used this information to calculate the managerial options ownership data. Information regarding stock ownership of management was obtained through the section Information about Beneficial Ownership of Principal Stockholders and Management which is also found on the proxy statement. In this section, firms report the amount and the type of ownership of multiple stockholders. We added the number of stocks that the top five named executive managers hold and multiplied it by the price of the stock at fiscal year-end, which was found either under data item 199 from Compustat or in the proxy statement.

\subsection{Business Segments}

Data about business segments were collected on the basis of the reportable segments of firms which are subject to regulation from the FASB. SFAS No. 131 Disclosures about Segments of an Enterprise and Related Information requires that a company with publicly traded debt or equity securities report annual and interim financial and descriptive information about its reportable operating segments. Operating segments are components of an enterprise for which separate 
financial information is available and such information is evaluated regularly by the chief operating decision maker when deciding how to allocate resources and assess performance.

Segments are generally organized either on the basis of business lines and type of products sold or on a geographic basis in function of the customer's country or region. Although most firms reported the same number of business segments through the years covered, it is possible that some firms had proceeded to a revision of their reporting segments due for example to acquisitions or discontinuances of operations. Data concerning reportable segments are disclosed in Item 1 of the annual report or in a note on business segments from the Notes to Consolidated Financial Statements under Item 8 of annual report on form 10-K. 


\section{References}

[1] Adam, T., S. Dasgupta and S. Titman (2008), "Financial Constraints, Competition and Hedging in Industry Equilibrium," Journal of Finance, forthcoming.

[2] Allayannis, G. and J. Weston (2001), "The Use of Foreign Currency Derivatives and Firm Value," Review of Financial Studies 14: 243-276.

[3] Allayannis, G. and E. Ofek (2001), "Exchange Rate Exposure, Hedging, and the Use of Foreign Currency Derivatives," Journal of International Money and Finance 20: 273-296.

[4] Becker, G.S. and K.M. Murphy (1993), "The Division of Labor, Coordination Costs, and Knowledge,"in Human Capital: A Theoretinal and Empirical Analysis, with sSpecial Reference to Education, 3rd ed., by G.S. Becker. Chicago: Univ. of Chicago Press.

[5] Bessembinder, H. (1991), "Forward Contracts and Firm Value: Investment Incentive and Contracting Effects," Journal of Financial and Quantitative Analysis 26: 519-532.

[6] Block, S.B., and T.J. Gallagher (1986), "The Use of Interest rate Futures and Options by Corporate Financial Managers," Financial Management 15: 73-78.

[7] Bodnar, G.M., G.S. Hayt and R.C. Marston (1998), "Wharton 1998 Survey of Risk Management by US Non-Financial Firms," Financial Management 27: 70-91.

[8] Bolton, P. and M. Dewatripont (1994), "The Firm as a Communication Network," Quarterly Journal of Economics 109: 809-839.

[9] Booth, J.R., R.L. Smith and R.W. Stolz (1984), "The Use of Interest Futures by Financial Institutions," Journal of Financial Economics 8: 3-29.

[10] Boyer, M. and J. Robert (2006), "Organizational Inertia and Dynamic Incentives," Journal of Economic Behavior and Organization 59(3), March 2006, 324-348.

[11] Boyer, M.M. and S. McCormack (2009), "The Use and Determinants of Derivatives Usage Amongst U.S. Manufacturing Firms," mimeo, HEC Montreal.

[12] Breeden, D., and S. Viswanathan (1996), "Why Do Firms Hedge? An Asymmetric Information Model," Duke University Working paper.

[13] Cummins, J.D. (1976), "Risk Management and the Theory of the Firm," Journal of Risk and Insurance 43: 587-609.

[14] De Angelis, D. and R. Garcia (2008), "A Multirisk Approach to Measuring Corporate Hedging and its Determinants," Cornell University, mimeo. 
[15] DeMarzo, P. and D. Duffie (1995), "Corporate Incentives for Hedging and Hedge Accounting," Review of Financial Studies 8: 743-771.

[16] Dessein, W., Garicano, L. and R. Gertner (2006), "Organizing for Synergies," mimeo, Graduate School of Business, University of Chicago.

[17] Doherty, N.A. and J.R. Garven (2006), "Noise Hedging and Executive Compensation," mimeo, Wharton School of the University of Pennsylvania.

[18] Doherty, N.A. and C.W. Smith (1993), "Corporate Insurance Policy: The Case of British Petroleum," Journal of Applied Corporate Finance, 6: 4-15..

[19] Fama, E.F. and M.H. Miller (1972), The Theory of Finance, Hinsdale: Dryden Press.

[20] Froot, K., D. Scharfstein and J. Stein (1993), "Risk Management: Coordinating Corporate Investment and Financing Policies," Journal of Finance 48: 1629-1658.

[21] Gable, L. and B. Sinclair-Desgagné (1997), "Environmental Auditing in Management Systems and Public Policy", Journal of Environmental Economics and Management 33: 331-346.

[22] Garicano, L. (2000), "Hierarchies and the Organization of Knowledge in Production," Journal of Political Economy 108: 874-904.

[23] Geczy, C., B. Minton and C. Schrand (1997), "Why Firms Use Currency Derivatives," Journal of Finance 52: 1323-1354.

[24] Graham, J.R. (2003), "Taxes and Corporate Finance: A Review," Review of Financial Studies 16: 1075-1129.

[25] Graham, J.R. and D.A. Rogers (2002), "Do Firms Hedge in Response to Tax Incentives?," Journal of Finance 57: 815-839.

[26] Graham, J.R. and C.W. Smith (1999), "Tax Incentives to Hedge," Journal of Finance 54: 2241-2262.

[27] Guay, W. and S.P Kothari (2003), "How much do firms hedge with derivatives?," Journal of Financial Economics 70: 423-461.

[28] Hart, O. and J. Moore (2005), "On the Design of Hierarchies: Coordination versus Specialisation," Journal of Political Economy 113(4): 675-702.

[29] Hannan, M.T. and J. Freeman (1984), "Structural Inertia and Organizational Change," American Sociological Review 49: 149-164. 
[30] Harris, M.S. (1998), "The Association between Competition and Managers' Business Segment Reporting Decisions," Journal of Accounting Research 36: 111-128.

[31] He, J. and L. Ng (1998), "The Foreign Exchange Exposure of Japanese Multinational Corporations," Journal of Finance 53: 733-753.

[32] Holmström, B. (1984), "On the Theory of Delegation," in Boyer, M. and R.E. Kihslstrom (eds), Bayesian Models in Economic Theory, North-Holland.

[33] Holmström, B. (1999), "The Firm as a Subeconomy," Journal of Law, Economics and Organizations 15: 74-102.

[34] Holmström, B. and P. Milgrom (1991), "Multitask Principal Agent Analyses: Incentive Contracts, Asset Ownership and Job Desing," Journal of Law, Economics and Organization 7: 24-52.

[35] Holmström, B. and J. Tirole (2000), "Liquidity and Risk Management," Journal of Money, Credit and Banking 32: 295-319.

[36] Jagannathan, R. and T. Ma (2003), "Risk Reduction in Large Portfolios: Why Imposing the Wrong Constraints Helps," Journal of Finance 58(4), 1651-1685.

[37] Jin, Y. and P. Jorion (2006). "Firm Value and Hedging: Evidence from U.S. Oil and Gas Producers," Journal of Finance 61: 893-919.

[38] Lessard, D. (1991), "Global Competition and Corporate Finance in the late 1990's," Journal of Applied Corporate Finance 3: 59-72.

[39] MacKay, P. and S.B. Moeller (2007), "The Value of Corporate Risk Management," Journal of Finance 52(3): 1379-1419.

[40] Main, B. (1983), "Corporate Insurance Purchases and Taxes," Journal of Risk and Insurance 50: $197-223$.

[41] Mayers, D. and C.W. Smith (1987), "Corporate Insurance and the Under Investment Problem," Journal of Risk and Insurance 54: 45-54.

[42] Mayers, D. and C.W. Smith (1990), "On the Corporate Demand for Insurance: Evidence from the Reinsurance Market," Journal of Business 63: 19-40.

[43] Merton, R. C. (1972), "An Analytic Derivation of the Efficient Portfolio Frontier," Journal of Financial and Quantitative Analysis 7: 1851-1872. 
[44] Mian, S.L. (1996). "Evidence on Corporate Hedging Policy," Journal of Financial and Quantitative Analysis 31: 419-439.

[45] Michaud, R. (1998), "Efficient Asset Management, A Practical Guide to Stock Portfolio Optimization and Asset Allocation," HBS Press.

[46] Modigliani, F. and M.H. Miller (1958), "The Cost of Capital, Corporation Finance, and the Theory of Investments," American Economic Review 48: 261-297.

[47] Mookherjee, D. (2006), "Decentralization, Hierarchies, and Incentives: A Mechanism Design Perspective," Journal of Economic Literature 64: 367-390.

[48] Nance, D.R., C.W. Smith and C.W. Smithson (1993), "On the Determinants if Corporate Hedging," Journal of Finance 48: 267-284.

[49] Ofek, E. and D.Yermack (2000). "Taking Stock: Equity-Based Compensation and the Evolution of Managerial Ownership," Journal of Finance, 55: 1367-1384.

[50] Roberts, D.J. (2004). The Modern Firm, Oxford University Press, New York (NY), 318 pages.

[51] Sinclair-Desgagné, B. (1999), "How to Restore Higher-Powered Incentives in Multitask Agencies," Jounal of Law, Economics and Organizations 15: 418-433.

[52] Smith, C.W. and R. Stulz (1985), "The Determinants of Firms' Hedging Policies," Journal of Financial and Quantitative Analysis 20: 391-405.

[53] Smithson, C. and B.J. Simkins (2005), "Does Risk Management Add Value? A Survey of the Evidence," Journal of Applied Corporate Finance 17: 8-17.

[54] Stulz, R.M. (1984). "Optimal Hedging Policies," Journal of Financial and Quantitative Analysis, 19: 127-140.

[55] Stulz, R.M. (1996), "Rethinking Risk Management," Journal of Applied Corporate Finance 9: $8-24$.

[56] Stulz, R.M. (2004), Risk Management and Derivatives, Thomson South-Western Publishers.

[57] Titman, S. (2002), "The Modigliani and Miller Theorem and Integration of Financial Markets," Financial Management 31: 1-21.

[58] Tufano, P. (1996), "Who Manages Risk? An Empirical Examination of Risk Management Practices in the Gold Mining Industry," Journal of Finance 51: 1097-1137. 
Table 1. Distribution of firms across industries

\begin{tabular}{cccc}
\hline Industry & SIC & Code & Number of firms \\
\hline Food & $2000-2099$ & 1 & 13 \\
Mining & $1000-1499$ & 2 & 11 \\
Construction & $1500-1999$ & 3 & 4 \\
Manufacturing & $2200-3999$ & 4 & 136 \\
Transportation & $4000-4799$ & 5 & 5 \\
Communications & $4800-4899$ & 6 & 4 \\
Utilities & $4900-4999$ & 7 & 12 \\
Wholesale & $5000-5199$ & 8 & 4 \\
Retail & $5200-5999$ & 9 & 25 \\
Finance & $6000-6599$ & 10 & 31 \\
Service & $7000-9999$ & 13 & 22 \\
Non-Classified & & 14 & 2 \\
\hline
\end{tabular}


Table 2. Estimated reactivity and use of financial derivative instruments by industry

This table reports the weighted average number of risks a firm hedges through the use of financial derivatives by industry as reported in the firms' $10-\mathrm{K}$ forms. Operational risks include commodity, equity and foreign exchange risks. Interest rate risk is the fourth possible risk that a firm can report being hedge. Industries are classified in decreasing order of their average estimated reactivity level. Reactivity is calculated as the $\gamma_{i}$ coefficient in the regression $\Delta P_{i t}=\alpha_{i}+\gamma_{i} \Delta \theta_{t}+\varepsilon_{i t}$, where $\Delta \theta_{t}$ is the annual variation in the market price of risk and $\Delta P_{i t}$ is calculated as $\sqrt{\left(S C O R_{i t}-S C O R_{i, t-1}\right)^{2}+\left(C F_{i t}-C F_{i, t-1}\right)^{2}} / V_{i t}$. The rank reports the industry's decreasing relative position in terms of the number of risks hedged ( 1 is the greatest user of hedging instruments).

\begin{tabular}{|cccccc|}
\hline Industry & $\begin{array}{c}\text { Estimated } \\
\text { reactivity } \\
\text { level }\end{array}$ & $\begin{array}{c}\text { Weighted number of } \\
\text { operational risks } \\
\text { hedged }\end{array}$ & $\begin{array}{c}\text { Weighted number } \\
\text { Rank }\end{array}$ & $\begin{array}{c}\text { total risks } \\
\text { hedged }\end{array}$ & Rank \\
\hline Utilities & 0.761 & 1.206 & 5 & 2.111 & 4 \\
Food & 0.679 & 1.758 & 2 & 2.622 & 2 \\
Conglomerates & 0.646 & 2.000 & 1 & 3.000 & 1 \\
Mining & 0.603 & 1.208 & 4 & 2.043 & 6 \\
Financial & 0.574 & 1.130 & 6 & 2.068 & 5 \\
Service & 0.551 & 1.673 & 3 & 2.462 & 3 \\
\hline Retail & 0.508 & 0.619 & 9 & 1.293 & 10 \\
Wholesale & 0.470 & 0.163 & 12 & 1.030 & 11 \\
Manufacturing & 0.451 & 1.028 & 7 & 1.609 & 8 \\
Communications & 0.328 & 0.521 & 10 & 1.521 & 9 \\
Transportation & 0.075 & 0.824 & 8 & 1.824 & 7 \\
Construction & -0.017 & 0.401 & 11 & 1.000 & 12 \\
\hline
\end{tabular}


Table 3. Firm reactivity and number of operational risks hedged

This table presents the multivariate ordered probit regressions that explain the number of operational risk a firm hedges. Reactivity is calculated as the $\gamma_{i}$ coefficient in the regression $\Delta P_{i t}=\alpha_{i}+\gamma_{i} \Delta \theta_{t}+\varepsilon_{i t}$, where $\Delta \theta_{t}$ is the annual variation in the market price of risk and $\Delta P_{i t}$ is calculated as $\sqrt{\left(S C O R_{i t}-S C O R_{i, t-1}\right)^{2}+\left(C F_{i t}-C F_{i, t-1}\right)^{2}} / V_{i t}$. Business segments is the number of segments a firm operates in as reported in Compustat. Log(Assets) is the natural logarithm of total assets of the firm. Dividend Yield is the dividend paid for the year by the firm divided by its stock price. MarketValue/BookValue is calculated as the market value of the firm's equity (stock price times the number of issued shares) divided by its book value. Long-term Debt/MarketValue is calculated as the value of the long-term debt divided by the market value of the firm (market value of equity plus book value of debt). $\mathrm{R} \& \mathrm{D} /$ Assets is calculated as research and development expenses divided by the total assets of the firm. Quick Ratio is the value of the currents assets minus the inventories divided by current liabilities. Foreign Sales Share is the percentage of the foreign sales over the total sales of the firm. NOL carryforward / Assets is calculated as the net operating losses carryforward divided by the firm's total assets. Log(Managerial Stock) is the natural logarithm of the stocks market value holdings of the top five managers. Log(Managerial Option) is the natural logarithm of the options market value holdings of the top five managers.

\begin{tabular}{|l|c|c|c|c|c|}
\hline & \multicolumn{2}{l|}{} & \multicolumn{2}{l|}{ Without Industry Controls } & \multicolumn{2}{l|}{ With Industry Controls } \\
\hline & Predicted Sign & Coefficient & Pvalue & Coefficient & Pvalue \\
\hline Reactivity & + & 25.1009 & 0.005 & 18.6416 & 0.025 \\
\hline Business Segments & + & 0.0890 & 0.040 & - & - \\
\hline Log(Assets) & + & 0.2986 & 0.002 & 0.3345 & 0.001 \\
\hline Dividend Yield & + & -0.0033 & 0.168 & -0.0054 & 0.021 \\
\hline Market Value / Book Value & + & -0.0007 & 0.591 & -0.0017 & 0.150 \\
\hline LT Debt/Market Value & + & -0.0084 & 0.412 & -0.0045 & 0.625 \\
\hline R\&D/Assets & + & 0.0464 & 0.983 & -0.6505 & 0.781 \\
\hline Quick Ratio & - & -0.0902 & 0.203 & -0.1297 & 0.076 \\
\hline Foreign Sales Share & + & 1.3793 & 0.000 & 1.2390 & 0.000 \\
\hline NOL carryforward/Assets & + & 2.0544 & 0.043 & 2.0320 & 0.048 \\
\hline Log (ManagerialShare) & + & -0.0527 & 0.319 & -0.0161 & 0.787 \\
\hline Log (ManagerialOption) & - & -0.0447 & 0.464 & -0.0211 & 0.743 \\
\hline & Pseudo R-square & \multicolumn{2}{|c|}{0.1225} & & 0.1638 \\
\hline
\end{tabular}


THE

FIRM

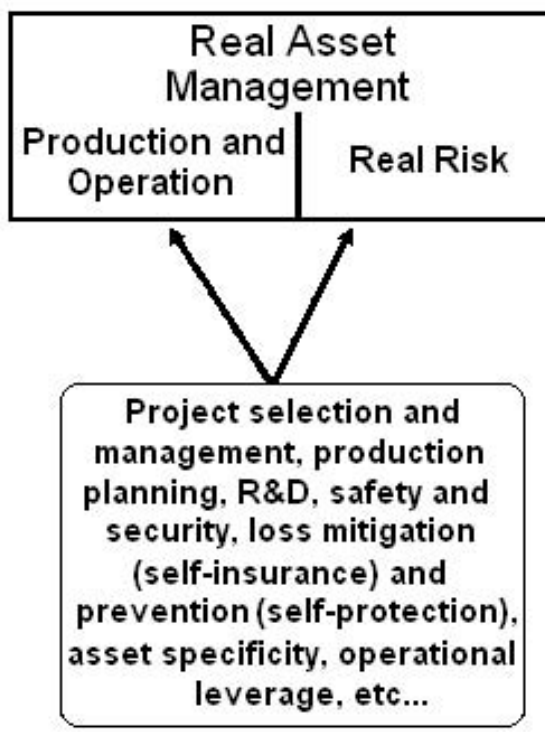

Financial Risk

Management

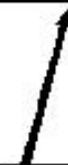

Financing, capital structure, forwards, futures, swaps, other derivatives, insurance and other financial market transactions, etc...

Figure 1: Production and operation management (POM), real risk management (RRM) and financial risk management (FRM) in the firm. 


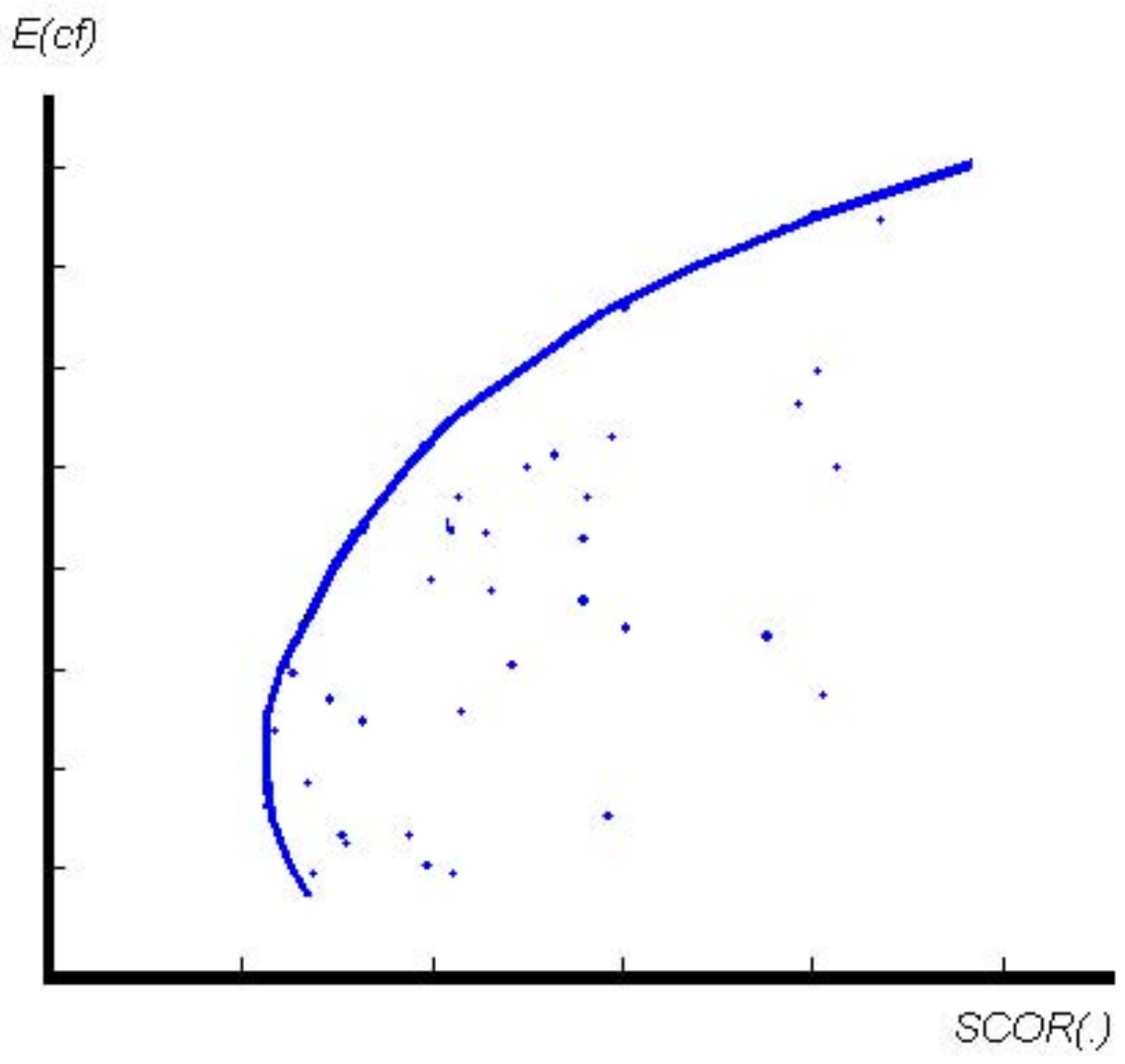

Figure 2: Efficient frontier given the portfolio of projects available to the firm. 


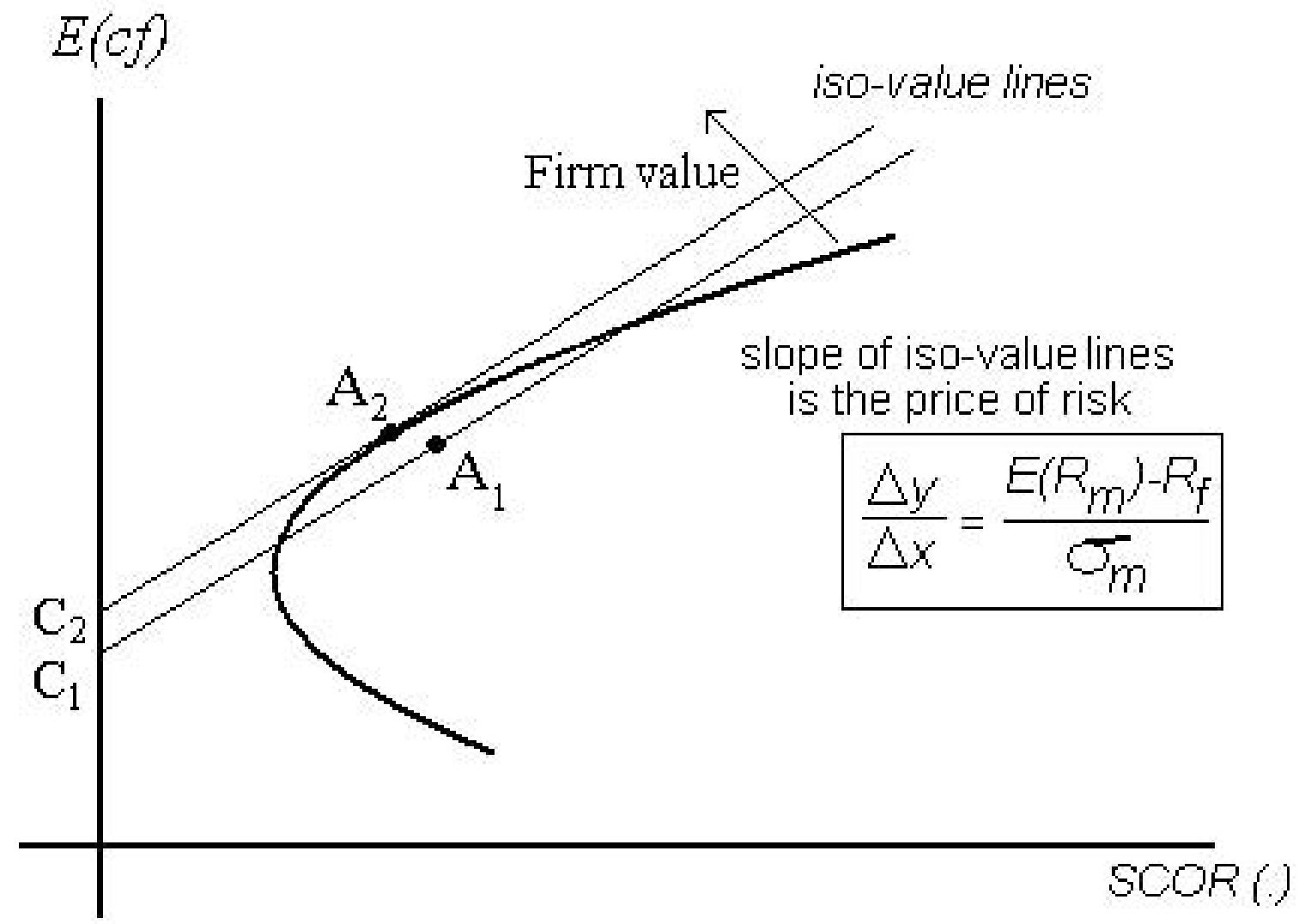

Figure 3: Efficient frontier and value maximization of the firm given the price of risk. 


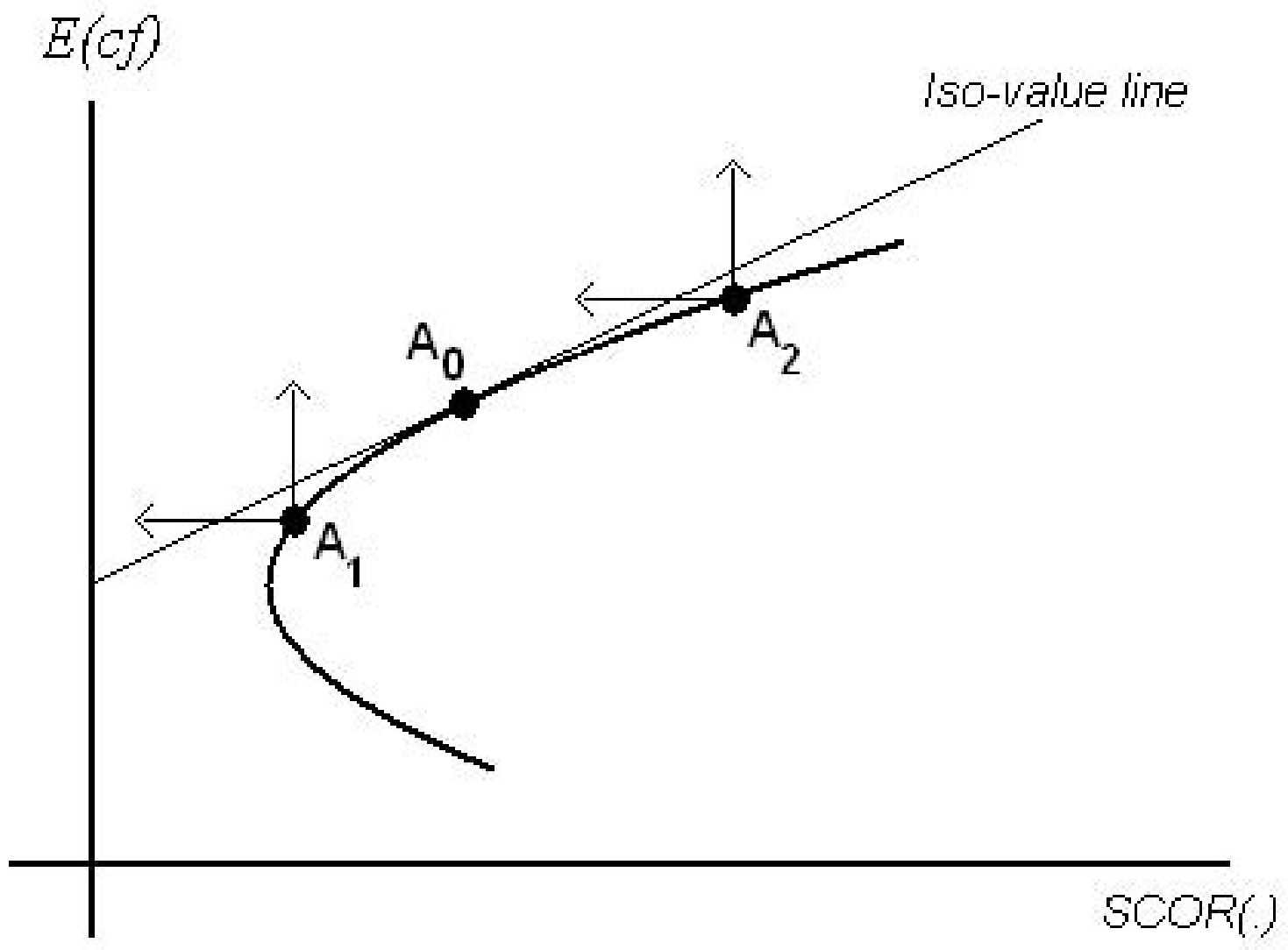

Figure 4: Coordination problems. 


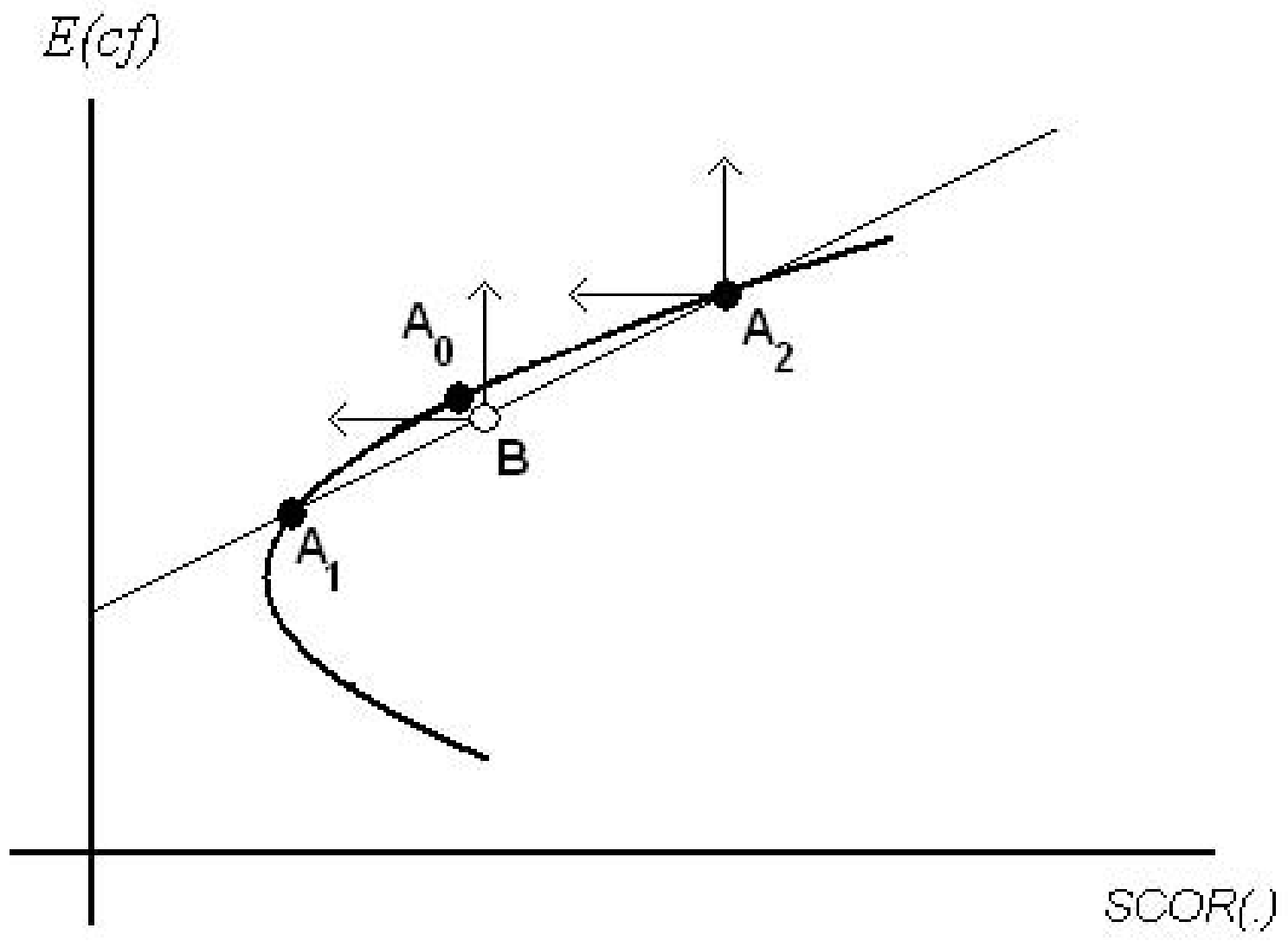

Figure 5: Value of financial risk management. 


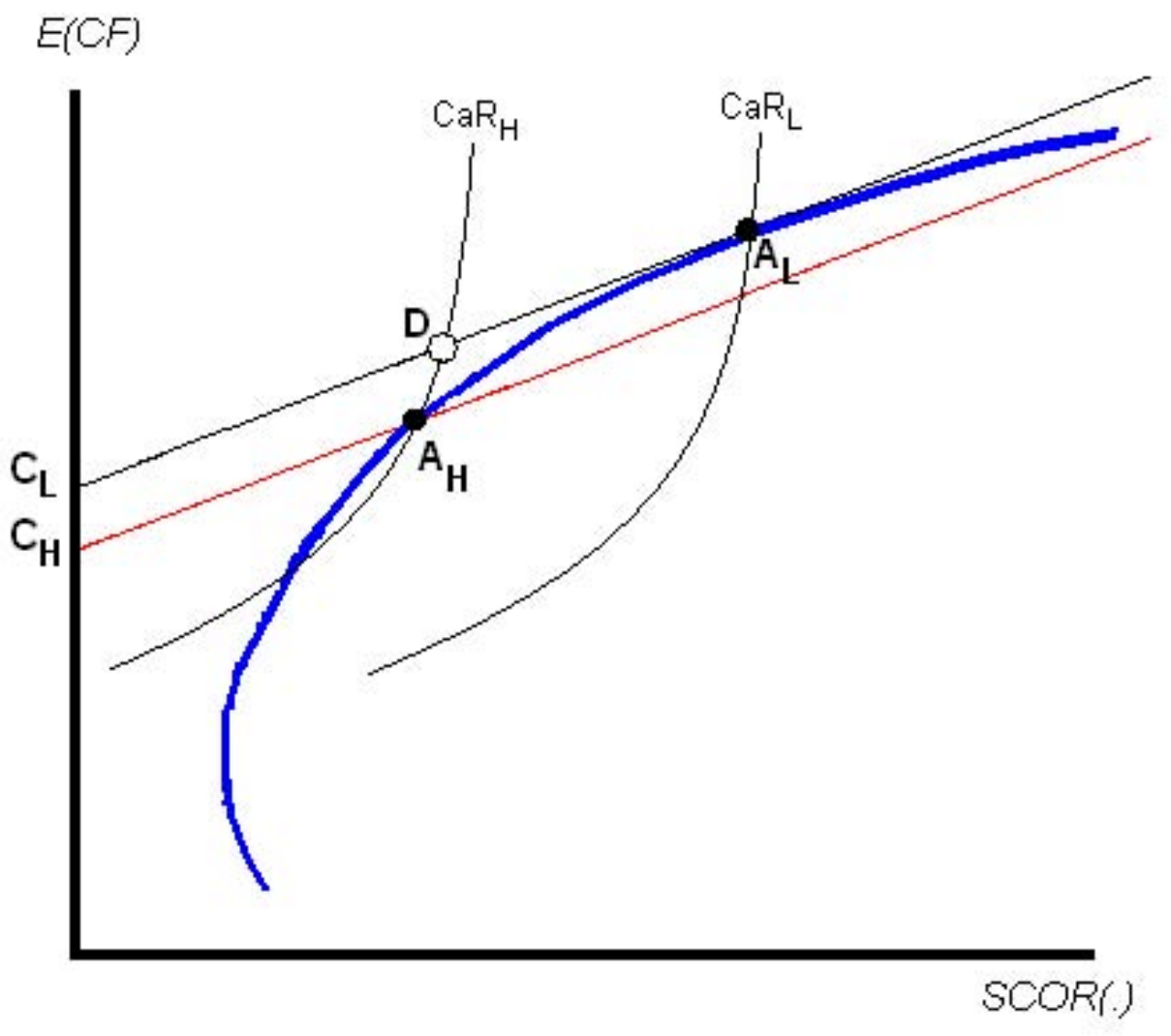

Figure 6: The value of using financial instruments for a firm constrained by $C a R$ requirements. 


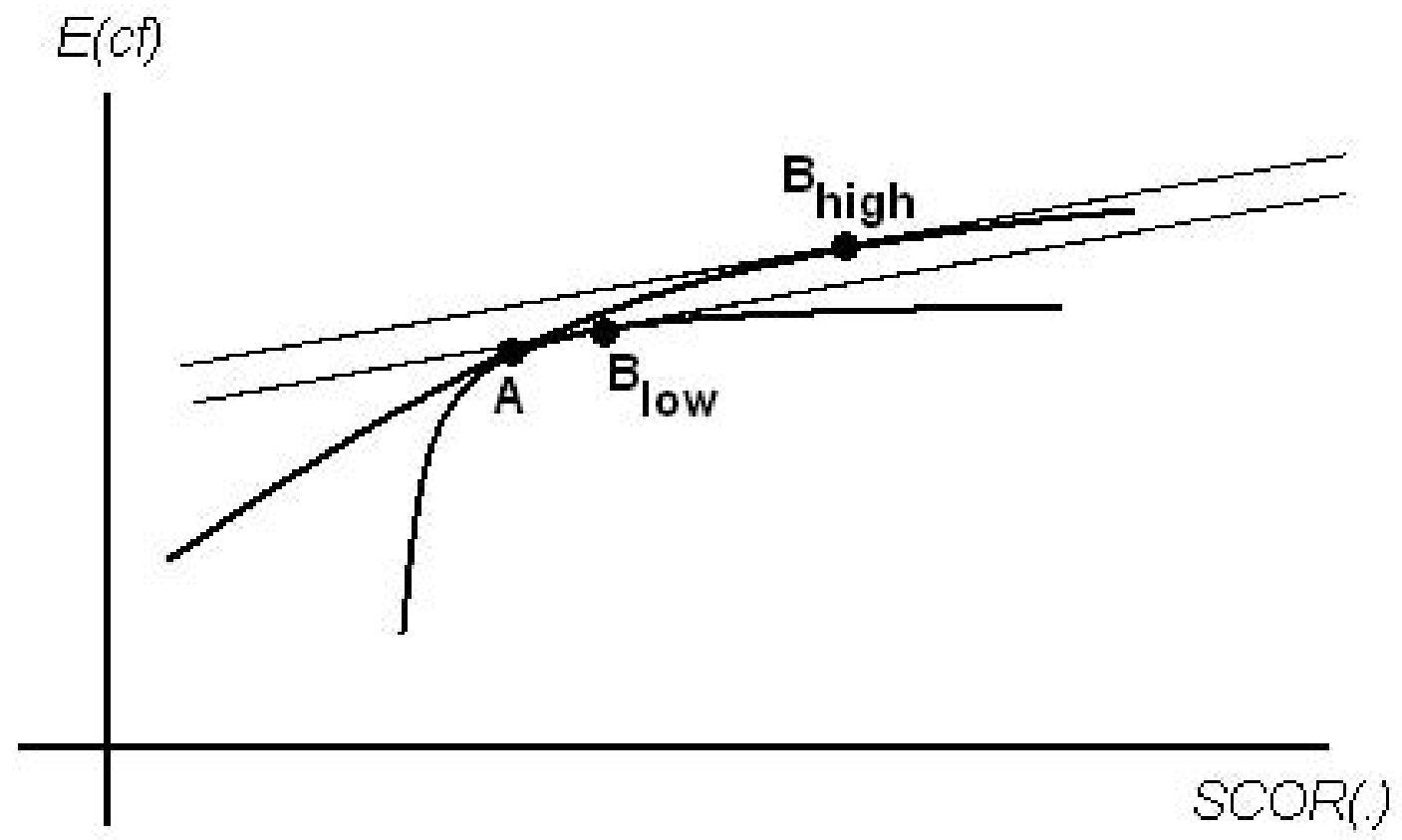

Figure 7: Impact of a change in the market price of risk on low and high concavity frontiers. 


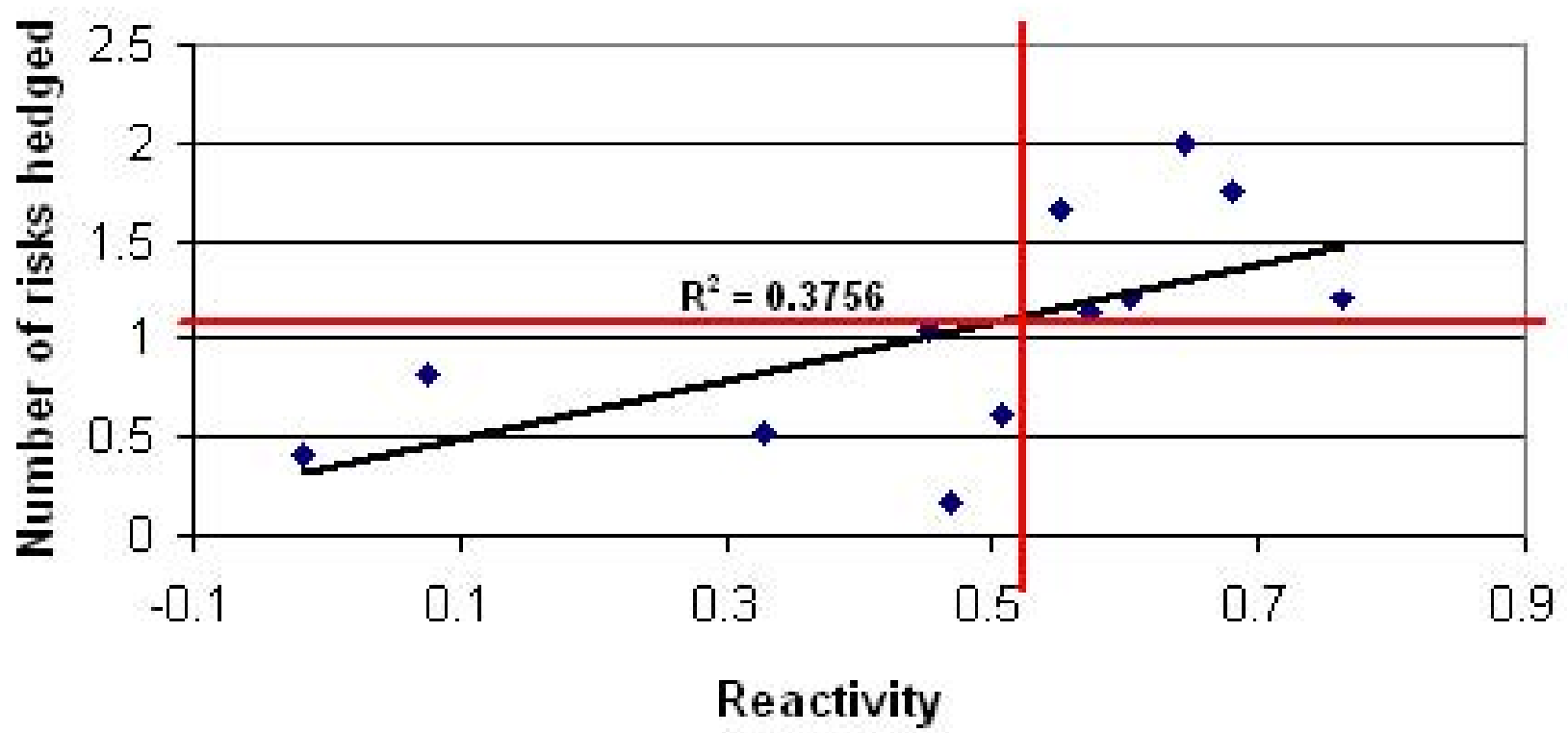

Figure 8: Number of Operational Risks Hedged as a Function of Reactivity by Industry. 